\title{
WORKING
}

paper

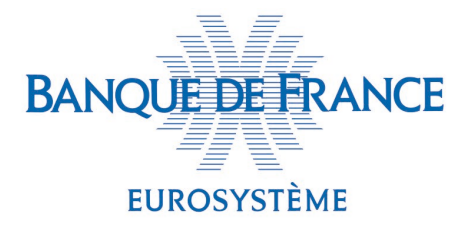

\section{Set-up Costs and the Financing of Young Firms}

\author{
François Derrien ${ }^{1}$, Jean-Stéphane Mésonnier², \\ Guillaume Vuillemey ${ }^{3}$
}

Revised version: June 2021, WP \#792

\begin{abstract}
We show that set-up costs are a key determinant of the capital structure of young firms. Theoretically, when firms face high set-up costs, they can only be established by leveraging up and lengthening debt maturity. Empirically, we use a large sample of French firms to show that young firms have a significantly higher leverage and issue longer-maturity debt than seasoned companies. As predicted by the model, these patterns are stronger in high set-up cost industries and for firms with lower profitability. Last, we show that, following an exogenous shock that reduces banks' supply of long-term loans, there is lower firm creation in high set-up cost industries.
\end{abstract}

Keywords: young firms, capital structure, set-up costs, leverage, debt maturity, financial frictions. JEL classification: D21, D22, D25, G32.

\footnotetext{
${ }^{1}$ François Derrien : HEC Paris (email: derrien@hec.fr).

2 Jean-Stéphane Mésonnier : Banque de France (email: jean-stephane.mesonnier@banque-france.fr).

${ }^{3}$ Guillaume Vuillemey : HEC Paris \& CEPR (email: vuillemey@hec.fr).

First version: December 2020. We are grateful to Denis Gromb and Martin Wagner for insightful discussions and to seminar participants at Banque de France, Bocconi University, BI Oslo, CEMFI, the Econometric Society World Congress 2020, the EIB, Goethe University, HEC Paris, Humboldt University, and the Tinbergen Institute for comments. This research benefited from funding from the Observatoire du Financement des Entreprises par le Marché and the Agence Nationale de la Recherche (F-STAR ANR17-CE26-0007-01).
}

The views expressed in this paper are those of the authors and should not be interpreted as reflecting the views of Banque de France or the Eurosystem. This document is available on publications.banquefrance.fr/en 


\section{NON-TECHNICAL SUMMARY}

Figure: balance sheet structure by set-up cost terciles

Total debt / Assets

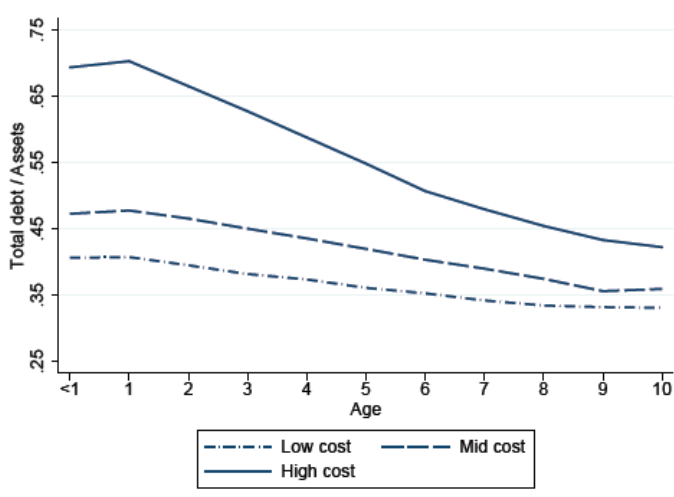

Maturity of total debt (in months)

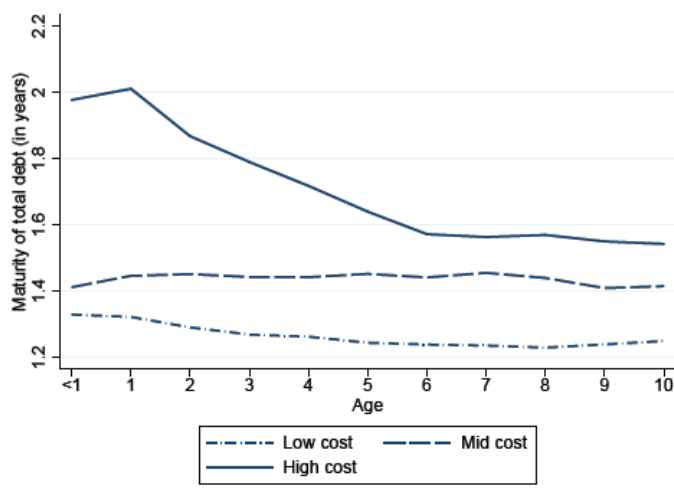

Despite the importance of young firms in the economy, little is known about their financing and their capital structure, due to severe data limitations. We start by documenting two facts using a large sample of French corporations: young firms have higher leverage and longermaturity debt than seasoned companies. These facts are a priori surprising if one accepts the usual assumption that young firms are more subject than older firms to adverse selection and moral hazard frictions. Indeed, in standard models, such frictions are associated with lower external financing of any type, whether equity or debt. Conditional on accessing debt markets, these models also predict low leverage and short-term maturities for the most constrained firms.

In this paper, we propose an explanation for these facts, and test a rich set of associated predictions. In sum, the key feature that can reconcile theory and data is the existence of fixed set-up costs, i.e., of a minimum quantity of tangible or intangible assets a firm needs to start operating in a given industry. When firms face set-up costs that are large relative to the entrepreneur's initial net worth, they need to turn to external financiers. Provided they have limited cash flows when they are young, their ability to repay debt each period is limited. The only way to finance set-up costs is thus to lengthen debt maturity, provided the debt contract remains feasible. These effects are magnified in industries in which setup costs are higher.

To formalize predictions on the role of set-up costs, we first develop a simple three-period model with moral hazard, inspired by Holmstrom and Tirole (1997). This model generates three main testable predictions. First, in industries with higher set-up costs, initial leverage and debt maturity are higher, and decline more quickly as firms age. Second, within industries characterized by a given set-up cost, firms with lower initial profitability should borrow with longer-term debt. Third, when the ability of financiers to supply longer-term debt is impaired, there can be heterogeneous effects across industries with different set-up costs: the patterns of firm creation and growth will differ across industries. In other words, set-up costs are not only important for firms' capital structure, but also for the transmission of bank shocks. 
Building on this simple model, our main contribution is empirical. We take these hypotheses to the data, using several sources, including balance sheet data on a random $20 \%$ of all firms created in France between 2006 and 2016, and detailed loan-level data from the Banque de France. We then turn to formal tests using regressions. This allows us to include a variety of controls, as well as firm and time fixed effects. We confirm the finding that, within a given firm and after removing time effects, leverage and debt maturity decrease with age. We additionally confirm that, within industries with a given set-up cost, firms with lower cash flows borrow with longer-maturity debt. In the second part of the paper, we show that set-up costs are an important determinant of the transmission of financial shocks to the real economy. We do so using a quasi-natural experiment: the failure in 2008 of Dexia, a large French-Belgian bank lending to French municipalities. Following this shock, municipalities previously relying on loans from Dexia increasingly borrowed, at long maturities, from other banks with whom they had pre-existing relationships. These banks were then constrained to cut the maturity of new loans to corporations. In difference-in-differences regressions, we confirm that treated banks reduced the maturity of new corporate loans after Dexia's failure. Firms in high set-up cost industries, for which the availability of longterm financing is more important, were more severely hit. As a last step, we find that maturity rationing by treated banks had real effects: in areas with a high concentration of banks affected by the shock, there is subsequently lower firm creation, specifically in high set-up cost industries.

\section{Coûts d'installation et financement des jeunes entreprises}

\footnotetext{
RÉSUMÉ

Nous montrons que les coûts d'installation sont un facteur déterminant de la structure du capital des jeunes entreprises. Théoriquement, lorsque les entreprises sont confrontées à des coûts d'installation élevés, elles ne peuvent être créées qu'en faisant appel à l'effet de levier et en allongeant la durée de la dette. Empiriquement, nous utilisons un large échantillon d'entreprises françaises pour montrer que les jeunes entreprises ont un levier nettement plus important et émettent des dettes à plus longue échéance que les entreprises plus anciennes. Comme le prévoit le modèle, ces tendances sont plus marquées dans les industries à coûts d'installation élevés et pour les entreprises à faible rentabilité. Enfin, nous trouvons que, suite à un choc exogène qui réduit l'offre de prêts à long terme de certaines banques, les créations d'entreprises sont moindres dans les industries à coûts d'installation élevés.

Mots-clés : jeunes entreprises, structure de capital, coûts d'installation, levier, maturité de la dette, frictions financières.

Les Documents de travail reflètent les idées personnelles de leurs auteurs et n'expriment pas nécessairement la position de la Banque de France. Ce document est disponible sur publications.banque-france.fr
} 


\section{Introduction}

Despite the importance of young firms in the economy, little is know about their financing and their capital structure, due to severe data limitations. We start by documenting two facts using a large sample of French corporations: young firms have higher leverage and longer-maturity debt than seasoned companies. These facts are a priori surprising if one accepts the usual assumption that young firms are more subject than older firms to adverse selection and moral hazard frictions. Indeed, in standard models (Stiglitz and Weiss, 1981; Diamond, 1991), such frictions are associated with lower external financing of any type, whether equity or debt. Conditional on accessing debt markets, these models also predict low leverage and short-term maturities for the most constrained firms.

In this paper, we propose an explanation for these facts, and test a rich set of associated predictions. In sum, the key feature that can reconcile theory and data is the existence of fixed set-up costs, i.e., of a minimum quantity of tangible or intangible assets a firm needs to start operating in a given industry. When firms face set-up costs that are large relative to the entrepreneur's initial net worth, they need to turn to external financiers. Provided they have limited cash flows when they are young, their ability to repay debt each period is limited. The only way to finance set-up costs is thus to lengthen debt maturity, provided the debt contract remains feasible. These effects are magnified in industries in which set-up costs are higher.

To formalize predictions on the role of set-up costs, we first develop a simple threeperiod model with moral hazard, inspired by Holmstrom and Tirole (1997). In this model, firms borrow at date 0 and repay financiers at dates 1 and 2, using cash flows that are subject to moral hazard. In this context, it is efficient for firms to repay debt as soon as possible in order to limit moral hazard problems that can arise in the future. However, firms' ability to repay debt early is limited by the magnitude of their early cash flows. Firms with high set-up costs or low early cash flows thus need to borrow with longer-term debt. Their ability to do so is itself limited by moral hazard problems, so that there is a selection of potential entrepreneurs into firm creation: entrepreneurs with too limited net worth cannot create firms, particularly if set-up costs are high.

This model generates three main testable predictions. First, in industries with higher set-up costs, initial leverage and debt maturity are higher, and decline more quickly as firms age. That is, the stylized fact discussed above is particularly strong in industries with high set-up costs. A corollary is that there is tougher selection in these industries: fewer entrepreneurs are able to enter. Second, within industries characterized by a given set-up cost, firms with lower initial profitability should borrow with longer-term debt. This prediction is again at odds with the received view that more constrained firms need to borrow with shorter-term debt. Third, when the ability 
of financiers to supply longer-term debt is impaired, there can be heterogeneous effects across industries with different set-up costs: the patterns of firm creation and growth will differ across industries. In other words, set-up costs are not only important for firms' capital structure, but also for the transmission of bank shocks.

Building on this simple model, our main contribution is empirical. We take these hypotheses to the data, using several sources, including balance sheet data on a random $20 \%$ of all firms created in France between 2006 and 2016, and detailed loan-level data from the Banque de France. These two sources of data allow us to overcome important data limitations that have plagued research on young and private companies so far. First, we present a set of stylized facts about the capital structure of young firms. In our sample, the ratio of total debt to assets falls from an average of $52 \%$ in the first two years of existence of firms to about $37 \%$ for 10 -year old companies. The maturity of the bank debt also decreases significantly with age. At the loan level, the average maturity of new loans falls from 72 to 54 months on average over the first ten years. We then classify 3-digit industries into terciles based on set-up costs, which we measure using the median value of tangible and intangible assets of young firms in each industry. Consistent with the model's predictions, the above patterns for leverage and maturity are almost entirely driven by firms operating in industries with high set-up costs. The ratio of total debt over assets decreases from about $70 \%$ to about $40 \%$ in the first ten years for firms in high set-up cost industries, while this proportion decreases much less, from about $40 \%$ to about $35 \%$ for firms in the lowest tercile of set-up costs. Similar patterns hold for debt maturity.

We then turn to formal tests using regressions. This allows us to include a variety of controls, as well as firm and time fixed effects. These fixed effects allow us to rule out the possibility that stylized facts are driven by selection, which could be the case if firms surviving until age 10 are systematically different from firms surviving only until age 2 . We confirm the finding that, within a given firm and after removing time effects, leverage and debt maturity decrease with age. We additionally test the second specific prediction from the model, namely that, within industries with a given set-up cost, firms with lower cash flows borrow with longer-maturity debt. We do indeed find that, after including fixed effects at the industry level, young firms with lower EBITDA borrow longer-term debt.

In the second part of the paper, we confirm the prediction that set-up costs are an important determinant of the transmission of financial shocks to the real economy. We do so using a quasi-natural experiment. Specifically, we exploit an event that exogenously forces some French banks to suddenly shorten the maturity of loans to corporations. This event is the failure in 2008 of Dexia, a large French-Belgian bank whose main business was to provide funding to local governments, notably municipalities. Following this shock, municipalities previously relying on loans from Dexia 
increasingly borrowed from other local banks with whom they had pre-existing relationships. Given that loans to municipalities have very long maturities, the duration mismatch between assets and liabilities increases mechanically for banks making these loans. To reduce this mismatch, they were constrained to cut the maturity of new loans to corporations. In difference-in-differences regressions, we confirm that treated banks (that is, banks heavily exposed to municipalities that were previously borrowing mostly from Dexia) significantly reduce the maturity of new corporate loans after Dexia's failure. More importantly, we do find that the effect picked up by the difference-in-differences estimation concentrates on firms in high set-up cost industries, for which the demand for long-term financing is more important. As a last step, we find that maturity rationing by treated banks had real effects: in areas with a high concentration of banks affected by the shock, there is subsequently lower firm creation, specifically in high set-up cost industries. Therefore, there is evidence for the selection patterns predicted by the model. More broadly, we confirm that set-up costs are a source of heterogeneity in the transmission of financial shocks.

Related literature. This paper contributes to three strands of the recent literature in corporate finance. First, it is related to the literature on the financial constraints of young firms. A number of papers study how financial factors, such as wealth (Evans and Leighton, 1989; Hurst and Lusardi, 2004), collateral constraints (Schmalz et al., 2017) or banking competition (Black and Strahan, 2002) affect the decision to become an entrepreneur. However, these papers are not primarily concerned with the capital structure of young firms, because of the lack of balance sheet data on private firms in most countries. ${ }^{1}$

A first exception is the paper by Robb and Robinson (2014), who use the Kauffman Firm Survey to show that young US firms rely heavily on external debt financing, in particular bank loans. Relative to this paper, we rely on panel data, which allow us to focus on time-series variation in the capital structure of young firms, and to use a quasi-natural experiment. Another exception is Dinlersoz et al. (2019), who also document a decreasing relationship between either leverage or debt maturity and age in a sample of young private US firms. They explain their findings based on the model by Albuquerque and Hopenhayn (2004), in which firms start to operate below their optimal scale, and build-up equity as they age, in order to escape financial constraints. While constraints are firm-specific in this model, we show that a large part of the variation in the data can be explained by industry-specific constraints arising from set-up costs. Relative to both Robb and Robinson (2014) and Dinlersoz et al. (2019), a novel message that our analysis conveys is indeed that set-up costs are an important

\footnotetext{
${ }^{1} \mathrm{~A}$ different literature focuses on the financing of innovation and innovative firms (Kerr and Nanda, 2015). We instead focus on the entire set of firms in the economy.
} 
feature for corporate finance researchers to consider in both theoretical and empirical work.

Second, this study relates to the literature on debt maturity choices by firms. A number of theoretical works show how short-term debt can mitigate information asymmetries (Diamond, 1991) and reduce inefficiencies associated with risk-shifting or debt overhang (Myers, 1977), while potentially creating rollover risk. Recent contributions consider these trade-offs in dynamic contexts (Diamond and He, 2014; He and Milbradt, 2016; Huang et al., 2019). The limited amount of empirical work on this topic finds support for the idea that contracting frictions explain part of the variation in firms' debt maturity (Barclay and Smith, 1995; Guedes and Opler, 1996; Custodio et al., 2013). We enrich this literature by showing that set-up costs are an important determinant of firms' debt maturity.

Third, the paper also contributes to the literature on the real effects of shocks to financial institutions. A number of papers study how negative shocks to the volume of bank loans supplied to firms impair their ability to invest or grow to reach optimal scale (see, among others, Peek and Rosengren, 2000; Chodorow-Reich, 2014; Cingano et al., 2016). Instead, we study a new type of shock, by which banks are forced to reduce the maturity, rather than the volume, of loans. The source of heterogeneity that we highlight in the transmission of banking shocks - cross-industry differences in set-up costs - is also novel. We show that such shocks can have substantial effects.

The remainder of this paper is organized as follows. Section 1 presents a simple model. Section 2 describes the data and the measurement of set-up costs. Section 3 presents stylized facts and tests the model's predictions on the role of set-up costs. Section 4 then investigates the real effects of set-up costs using a quasi-natural experiment.

\section{Model and testable predictions}

We present a simple model of external financing with fixed set-up costs, building on Holmstrom and Tirole (1997), and use it to generate testable predictions.

\section{$1.1 \quad$ Setup}

There are three periods, $t \in\{0,1,2\}$. There is a continuum of industries $i$, each with a fixed cost of starting a firm, denoted by $I \geq 0$ and distributed over $[\underline{I}, \bar{I}]$ with density $f(I)$. This set-up cost can be interpreted as the minimum quantity of equipment, intangible assets or commercial property an entrepreneur needs to start a firm in a given industry. Within each industry, there is a continuum of entrepreneurs $a$ with 
initial resources $A \geq 0$ distributed over $[\underline{A}, \bar{A}]$ with density $g(A)$. To start the project, an entrepreneur needs $D=\max \{I-A, 0\} .^{2}$ All agents are risk-neutral. Entrepreneurs have no time preference, and lenders have a discount factor $\beta<1$ between dates 1 and 2. This discount factor can be interpreted as measuring the reluctance of lenders to engage in long-term debt.

When undertaken, the project yields a safe cash flow $e$ at date 1 . At date 2, it yields a risky verifiable cash flow $R>0$ with probability $p$, and no cash flow with probability $1-p$. The entrepreneur is subject to moral hazard. When he exerts effort, the probability of success is $p=p_{H}$ and there is no private benefit to the entrepreneur. When the entrepreneur misbehaves, the probability of success is $p=p_{L}<p_{H}$, but the entrepreneur enjoys a private benefit $B \geq 0$. Importantly, the decision to exert effort is taken by the entrepreneur at date 1 , after cash flow $e$ is realized. While simplifying, this assumption captures the intuition that multiperiod projects may require effort to be exercised throughout the life of the project. We assume that the project is viable only if the entrepreneur behaves, that is

$$
e+p_{H} R>I>e+p_{L} R+B .
$$

Therefore, no loan that gives an incentive to misbehave will be granted.

\subsection{External financing}

The loan contract specifies how cash flows are shared between the lender and the entrepreneur, subject to limited liability. Cash flows to the lender at dates 1 and 2 are denoted $L_{1}$ and $L_{2}$, while cash flows to the entrepreneur are denoted $W_{1}$ and $W_{2}$. We assume that lenders are perfectly competitive. Their participation constraint is such that they make zero profit in expectation,

$$
L_{1}+\beta p_{H} L_{2}=D
$$

provided that the entrepreneur exerts effort.

Furthermore, the loan agreement must preserve the entrepreneur's incentives to behave, that is, an agency rent must be given. His incentive compatibility constraint is

$$
W_{1}+p_{H} W_{2} \geq W_{1}+p_{L} W_{2}+B
$$

that is, $\Delta p W_{2} \geq B$, where $\Delta p=p_{H}-p_{L}$. At date 1 , after $e$ is realized, the highest income that can be pledged to lenders in case of success is $R-B / \Delta p$, so that date-1

\footnotetext{
${ }^{2}$ It is never optimal for the entrepreneur to invest less than $A$ and thus to borrow more that $I-A$.
} 
expected pledgeable income is

$$
p_{H}\left(R-\frac{B}{\Delta p}\right)
$$

Because lenders must break even, a loan is feasible only if

$$
L_{1}+\beta p_{H}\left(R-\frac{B}{\Delta p}\right) \geq D
$$

Whenever the set-up cost is large relative to the entrepreneur's resources (that is, $I>A$ so that $D>0$ ), some firms may not obtain external financing. Indeed, only entrepreneurs with initial resources $A \geq A^{*}(I, \beta)$ will get funding, where

$$
A^{*}(I, \beta)=I-L_{1}-\beta p_{H}\left(R-\frac{B}{\Delta p}\right) .
$$

Intuitively, entrepreneurs with insufficient own resources must borrow a large amount, and thus pledge a large fraction of the date- 2 return in case of success. Being left with a small fraction of returns, the entrepreneur has little incentives to exert effort and prefers to shirk. No contracting arrangement makes the project feasible when $A<A^{*}(I, \beta)$. Furthermore, $A^{*}(I, \beta)$ is increasing in $I$. Therefore, a lower proportion of projects obtain financing in industries with high set-up costs: there is stronger selection of new firms in these industries. A corollary is that firms operating in high set-up cost industries have higher average capitalization $A$ (in dollar terms).

Next, Equation (6) makes it possible to solve for the optimal debt repayment schedule. Indeed, $A^{*}(I, \beta)$ is decreasing in $L_{1}$. Therefore, it is always optimal to make sure the entrepreneur repays as much as possible at date 1 , that is,

$$
L_{1}=\min \{e, D\} \quad \text { and } \quad L_{2}=\max \{D-e, 0\}
$$

Intuitively, repaying as much as possible early on makes it possible to minimize the moral hazard problems that arise later on. When a larger fraction of the debt is repaid at date 1 , a smaller amount has to be repaid at date 2, and the entrepreneur appropriates a larger fraction of the benefits from exerting effort.

Finally, we study the effect of changes in the discount factor $\beta$ on the share of firms being financed across industries. Variation in $\beta$ can be interpreted as reflecting changes in lenders' opportunity cost of providing long-term funding (for example due to unmodeled liquidity risk management or regulatory reasons). Denote by

$$
m(I, \beta)=\int_{A^{*}(I, \beta)}^{\bar{A}} g(A) \mathrm{d} A,
$$

the mass of firms obtaining financing in any given industry characterized by a set-up cost $I$. From the definition of (6), we see that $\partial m(I, \beta) / \partial \beta>0$, that is, the mass of 
firms obtaining financing is larger when lenders are more willing to provide long-term funding (larger $\beta$ ), regardless of $I$. However, we are interested in the sign of

$$
n(I, \beta)=\frac{\partial}{\partial I}\left[\frac{\partial m(I, \beta)}{\partial \beta} / m(I, \beta)\right],
$$

that is, we want to know, for a given change in $\beta$, whether the share of firms being financed changes differentially across industries with different set-up cost $I$. The decrease in the share of financed firms is larger in high set-up cost industries whenever $n(I, \beta)>0$. From (6) and (8), it is straightworward to show that

$$
n(I, \beta)>0 \quad \text { if } \quad \frac{\partial g\left(A^{*}(I, \beta)\right)}{\partial I} \cdot m(I, \beta)+g\left(A^{*}(I, \beta)\right)>0 .
$$

While the second term in (10) is always positive, the sign of the first term is indeterminate and depends on the sign of $\partial g\left(A^{*}(I, \beta)\right) / \partial I$, that is, ultimately, on the specific form of the distribution $g($.$) . Therefore, for unspecified distributions of entrepreneurs'$ net worth, it is not possible to claim that high set-up cost industries are more or less affected by changes in $\beta$. However, once standard distributions are assumed, exact predictions can be derived. In the simplest case of a uniform distribution $g($.$) , we have$ $\partial g\left(A^{*}(I, \beta)\right) / \partial I=0$, which implies that $n(I, \beta)>0$ : in that case, high set-up cost industries are relatively more affected by changes in the availability of long-term debt.

\subsection{Empirical predictions}

The model yields three main testable predictions. The first one pertains to the capital structure of new firms in the cross-section of industries.

Hypothesis 1. (Debt maturity across industries) For a given level of initial resources, conditional on operating the project, firms in industries with higher set-up costs borrow with longer-maturity debt.

This prediction follows from the fact that, for a given level of initial resources $A$, firms in high set-up cost industries have greater need for external financing $D=$ $\max \{I-A, 0\}$. For a given level of date- 1 cash flow $e$, the ratio $L_{2} / L_{1}$ is higher (by Equation 7), that is, debt maturity is longer. ${ }^{3}$ A corollary prediction is that, for a given level of initial resources, conditional on operating the project, firms in industry with a higher set-up cost have higher leverage.

\footnotetext{
${ }^{3}$ The model's predictions arising from Equation (7) are about the share of total debt repaid in period 2, not about debt maturity in a strict sense. Indeed, a high share of date-2 repayments could be implemented by rolling over a large share of one-period debt contracts at date 1 . To give empirical content to Equation (7), and derive Hypotheses 1 and 2, we interpret the term structure of repayments $\left(L_{1} / L_{2}\right)$ as debt maturity. This amounts to assuming that there are (unmodeled) costs associated with debt rollover. Both the theoretical and the empirical literature provide evidence for such costs (He and Xiong, 2012; Almeida et al., 2012).
} 
Hypothesis 2 turns to within-industry predictions.

Hypothesis 2. (Debt maturity within industries) Within an industry, conditional on operating the project, more financially constrained firms have longer-term debt.

This prediction follows from Equation (7). A natural measure of financial constraints in the model is given by the relative magnitude between $D$ and $e$. When $D$ is large relative to $e$, the firm has a lot of debt relative to early cash flows, and must thus repay most of the debt at date 2 (i.e., the debt is mostly long-term). Instead, in case $e$ is large relative to $D$, all of the debt is repaid at date 1 and is thus short-term.

Hypothesis 3. (Supply of loanable funds) A negative shock to the supply of longterm financing implies that firms with sufficiently high set-up costs no longer operate.

This prediction follows from the analysis in the previous section. A drop in $\beta$ is associated with a change in the industry composition of new firms: industries with high set-up costs should be underrepresented after the shock.

The predictions from the model are illustrated in Figure 1, which plots the variables of interest given a particular set of parameters. Panels A and B illustrate Hypothesis 1 by showing that, for a given net worth and conditional on obtaining financing, firms in industries with high set-up costs operate with a larger share of long-term debt and with higher leverage. Panel $\mathrm{C}$ illustrates Hypothesis 2 by showing that, for a given net worth and conditional on obtaining financing, firms with lower profitability operate with a larger share of long-term debt. Finally, Panel D shows that, when $g(A)$ is a uniform distribution, a lower supply of long-term external finance (lower $\beta$ ) is associated with a lower share of high set-up costs projects being financed. This is consistent with Hypothesis 3.

\section{Data and measurement of set-up costs}

We now describe the data and the measurement of set-up costs.

\subsection{Data}

Our analysis uses two different samples. First, a firm-level sample, in which we observe a large panel of firms and a wide range of accounting information about them. Second, a sample of loans, with detailed information at the loan level. In this section, we describe these two main data sources in greater detail, as well as other data sources that we use in some analyses to construct auxilliary variables.

The first main dataset used in subsequent analyses is a firm-level panel, which contains balance sheet and income statements data that we obtain from firms' tax 
filings. Our main sample is based on a random draw of $20 \%$ of the universe of all firms which were created in France between 2006 and 2016, after excluding self-employment and financial firms. After a firm is created, we observe yearly balance sheets and income statements until failure (if any), corresponding to 663,465 firm-year observations (for 168,577 unique firms). The data allow us to measure firms' debt structure (bank debt, other financial debt, and trade credit), broken down by residual maturity buckets $(\leq$ 1 year, 1 year $<$. $\leq 5$ years, 5 years $<$ ). These data are retrieved from Diane (Bureau van Dijk). ${ }^{4}$

Our second main dataset uses proprietary data from the Bank of France ( $M$ Contran) on the detailed characteristics of new bank loans to firms, including their initial maturity. This dataset covers all loans granted by a random set of domestic bank branches during the first month of each quarter. While not a panel (since the set of surveyed bank branches rotates over time), these data have advantages over standard credit registers. Indeed, credit registers typically aggregate old and new loan exposures at the bank-firm level, so that no information on specific loan terms (initial maturity, interest rate, etc.) is available. We restrict the sample to loans financing corporate investment, which leaves us with 114,703 unique loans between 2006Q1 and 2018Q2 if we consider all firms aged up to 10 years (i.e., the age limit, by construction, of firms in the Diane sample above). In most exercises, we however focus on loans issued to young firms, which we define throughout (unless otherwise specified) as firms in their first two years of existence (aged less than 24 months). This leaves us then with 37,188 investment loans, issued to some 30,000 different firms. We retrieve the complete tax filings of these new firms from Diane whenever this information is available. ${ }^{5}$ The distribution of young firms across industries in this second dataset comes out as quite close to the one we observe in the first dataset. Descriptive statistics on the two datasets, the firm-level one and the loan-level one, are reported in Table 1.

We complement these two datasets with information from two other sources. First, we use the French credit register to construct additional variables that we use in our quasi-natural experiment (Section 4). The register records all bilateral credit exposures at the bank branch-vs-borrower level (above a small reporting threshold of EUR 25,000 , including off-balance sheet guarantees). Whatever the type of borrower, we define total bilateral credit exposures by adding outstanding loans and undrawn credit lines. The credit register collects information on all types of borrowers (except individual borrowers, i.e., households) from banks operating in France, at a monthly frequency. In particular, we exploit information on bank loans to non-financial corpo-

\footnotetext{
${ }^{4}$ Diane has the drawback that failing firms are removed from the dataset after three years. To ensure that our results are not driven by survival biases, we later test firm-level predictions after including firm fixed effects.

${ }^{5}$ As a matter of fact, the relevant financial ratios (e.g., leverage, profitability, tangible assets to assets) can be computed for about a fifth of these firms only.
} 
rations and to local governments and selected other local administrative entities, which we denote throughout as "municipalities". Municipalities mostly refer in this paper to the 36,464 French municipalities in a strict sense (representing about $40 \%$ of domestic bank lending to all local public entities according to the French credit register in 2007), but we also include the 22 regions (9\%) and 96 counties (17\%) of mainland France (as of 2007), as well as major groupings of municipalities (communautés de communes, de villes, d'agglmération, about $13 \%$ of credit), major types of special purpose vehicles ("syndicates") set up by municipalities (SIVOM, SMO, SMF, around $8 \%$ of credit), as well as municipal social housing societies and consular chambers. Together, these local governments and local public administrative entities account for more than $95 \%$ of credit by resident banks to local governments and administrative entities in France. ${ }^{6}$

Last, we also use another dataset from the Banque de France, called CEFIT, to compute measures of bank competition in local corporate credit markets at the level of the French equivalent of counties (namely, départements). ${ }^{7}$ The CEFIT database collects the total amount of loans granted by each individual chartered bank in each county, with breakdowns by loan types and borrower types (corporations, households, public administrations). Data is available since 2006 and we compute Herfindhal indexes of concentration in local corporate credit markets using data for 2007, i.e. before the shock we are considering.

\section{$2.2 \quad$ Measuring set-up costs}

A key variable of interest in the model is the fixed set-up cost for firms in a given industry. We estimate set-up costs at the 3-digit industry level as follows. First, in our full sample of young firms (i.e., our main firm-level dataset, based on Diane), we keep firms with age strictly below 24 months, where firm age in year $t$ is defined as the difference between the reporting year of the balance sheet $(t)$ and the year of firm creation $\left(t_{0}\right) .{ }^{8}$ Second, for each firm $f$ in industry $i$, we compute the set-up cost $S U C_{f}^{i}$, equal to the initial investment needed to set-up the company and start operating. $S U C_{f}^{i}$ is the mean value of both property, plant and equipment $(P P E)$ and intangible assets $(I A)$, in euros, over the first two years of existence of firm $f$ (denoted

\footnotetext{
${ }^{6}$ Excluded legal categories of local public entities (about 30 other types) are either largely irrelevant (e.g., school cashboxes or municipal pawnshops) or do not rely much on bank credit for funding, as they represent each less than $1 \%$ of total bank credit to local public bodies. We denote the included local entities as "municipalities" throughout for simplicity.

${ }^{7}$ We consider all counties in mainland France, excluding Corsica and French overseas counties and territories (DOM-COM). Mainland France is partitioned into 96 counties.

${ }^{8}$ For instance, consider a firm created officially in September 2010. In the reporting year 2010, this firm is aged "0 year" in our dataset. In the reporting year 2011, this firms is aged "1 year".
} 
here years 0 to 1$)^{9}$,

$$
S U C_{f}^{i}=\frac{1}{2} \sum_{t=0}^{t=1}\left[P P E_{f t}+I A_{f t}\right] .
$$

Next, for each 3-digit industry $i$, we measure set-up costs as the median of $S U C_{f}^{i}$ over all firms $f=1, \ldots, F^{i}$ in industry $i$,

$$
S U C_{i}=\operatorname{median}\left\{S U C_{1}^{i}, \ldots, S U C_{F}^{i}\right\}
$$

Taking the median, rather than the minimum, prevents mismeasurement arising from a few anomalous observations (e.g., firms that are legally created but never operate). ${ }^{10}$

We provide descriptive statistics on set-up costs in Table 2. Panel A shows moments of the distribution of set-up costs across the 146 industries for which the measure exists. There is significant cross-sectional variation in set-up costs across industries: the median industry has a set-up cost of 19,000 euros, while the cost jumps to 121,000 euros at the 90 th percentile. Panel B reports the 15 industries with the highest and lowest set-up costs. Not surprisingly, industrial activities tend to have high set-up costs (e.g., manufacture of paper products, quarrying of stone, sand and clay), while services relying primarily on human capital have low set-up costs (e.g., translation and interpretation activities, business support service activities). ${ }^{11}$

Panel C of Table 2 presents the correlation between selected balance sheet characteristics of firms and industry-level set-up costs. It shows regressions of balance sheet characteristics on a constant and on two dummy variables capturing whether the firm operates in an industry either in the second (MidCost) or third (HighCost) tercile of the set-up cost distribution. Relative to firms in the lowest tercile, firms in high set-up cost industries have significantly higher ratios of PPE/Assets and Intangibles/Assets (by 16.3 and 22.2 percentage points, respectively) when they start operating. Thus, firms in high set-up cost industries not only require a large absolute amount of tangibles and intangibles to operate, but these assets also represent a large proportion of their balance sheets. Finally, firms in these industries also start with significantly larger size (i.e., more total assets). These differences are persistent when firms age, as can be seen in columns 4 to 6 of the table. In a similar vein, Appendix Figure A1 shows that set-up costs correlate positively with four industry-level characteristics: average capital expenditure, PPE, size, and dependence on external finance, as defined

\footnotetext{
${ }^{9}$ Alternatively, we could consider the maximum of $P P E$ and $I A$ between years 0 and 1 . However, this does not change the ranking of industries in terms of set-up costs.

${ }^{10}$ To further avoid mismeasurement, we restrict the sample to 3-digit industries with at least 15 different firms with non-missing PPE in year 0 or 1.

${ }^{11}$ The rankings of industries look highly similar if we compute set-up costs using tangible assets (PPE) only. Furthermore, while we cannot precisely measure leasing, correlations show that leasing expenses are more common in industries with high tangible assets. Therefore, the omission of leasing is unlikely to revert the ranking of industries. Since our tests never rely on the numerical values of set-up costs, but only on their rankings (by terciles), leasing is unlikely to affect our results.
} 
by Rajan and Zingales (1998). ${ }^{12}$ To ensure that these correlations with other industry characteristics are not driving our results, we use various combinations of firm controls and fixed effects in our subsequent tests.

\section{Stylized facts and empirical tests}

This section presents stylized facts about the capital structure of young firms, and tests the model's predictions on the role of set-up costs.

\subsection{Stylized facts}

We start by plotting several variables of interest to establish stylized facts about the capital structure of young firms. In Figure 2, we display the mean value of several firm characteristics between creation and age 10 years, in the pooled sample of newlycreated firms. The top-left panel shows that leverage decreases with age, from an average ratio of total debt to assets of about $52 \%$ in the first 24 months of existence, to a ratio of $37 \%$ at age 10 years. The top-right panel studies the average maturity of total debt, measured as:

$$
\text { Maturity }_{i t}=12 \cdot \frac{\text { Debt } \leq 1 \mathrm{y}}{\text { Total debt }}+36 \cdot \frac{\text { Debt } \in(1 \mathrm{y}, 5 \mathrm{y}]}{\text { Total debt }}+84 \cdot \frac{\text { Debt }>5 \mathrm{y}}{\text { Total debt }},
$$

that is, by assigning maturities of 12, 36 and 84 months to debt in each of the reported buckets. We find that the average maturity of total debt is also decreasing with age, from about 19 to about 16 months over the first 10 years.

Both patterns on leverage and maturity are surprising from the viewpoint of a number of received theories. Indeed, if young firms are subject to more severe financial frictions (e.g., more information asymmetries or greater commitment problems), we should expect them to have a harder access to external finance, thus to borrow less and with shorter-term debt. ${ }^{13}$ They are instead consistent with our model. The last three panels of 2 show that the decrease in total debt over firms' lifetime is primarily driven by bank debt (which is cut by half, from about $20 \%$ to about $10 \%$ of total assets), and to a lesser extent by other financial debt (which decreases from about

\footnotetext{
${ }^{12}$ While these results are computed using the sample of firms from Diane, that is, firms with age up to 10 years, they are robust to using a sample of mature firms from the Banque de France (FIBEN, which reports the balance sheets and income statements of all legal units incorporated in France with annual sales above 700,000 euros).

${ }^{13}$ This chart is potentially consistent with the pecking order theory (Myers and Majluf, 1984): If equity is more costly to issue than debt due to more severe adverse selection problems, then firms should first issue debt, and issue equity as they age, thus reducing leverage. However, this explanation is unlikely to explain the stylized facts: the small private firms in our sample virtually never issue external equity; the increase in book equity almost entirely comes from retained earnings.
} 
$15 \%$ to about $10 \%$ of total assets). This fact is also surprising, since bank debt is a priori subject to more severe financial frictions than other financial debt (which is obtained from equityholders, that is, mainly family and friends for young firms), and could thus be expected to grow more over time. However, the fact that bank debt decreases much more with age than other financial debt (obtained from equityholders) is consistent with the model, if the latter is subject to milder moral hazard problems than the former. Indeed, when moral hazard problems are not severe (as is arguably the case for family and friends), there is no gain from repaying most of the debt early on. Finally, the ratio of payables to total assets is stable over the lifetime of firms, in line with the view that the general pattern that we document is not related to firms' operations but to the financing of fixed assets.

Next, we provide preliminary evidence in Figure 3 that set-up costs are critical to explain these patterns. We reproduce the same charts as in Figure 2, after breaking down the sample based on whether firms operate in industries with low, intermediate or high set-up costs (based on terciles across industries, as defined previously). For both leverage and maturity, the aggregate patterns are overwhelmingly driven by industries with high set-up costs. For industries in the top tercile of set-up costs, leverage is cut by close to $40 \%$ over the first 10 years (from $70 \%$ to $43 \%$ ) while the decrease is much less pronounced for firms in other industries. Regarding maturities, the patterns are even more striking. For firms operating in industries with low or intermediate set-up costs, debt maturity is stable with age. The decrease in maturity is strong only for firms in high-set-up cost industries (from about 24 to about 18 months). The three subsequent panels confirm that bank debt is the main driver of this pattern. Finally, Figure 3 also confirms that there is no age pattern in terms of payables regardless of the set-up cost, which is reassuring since the model does not make any prediction for this specific type of debt.

While all these figures are consistent with the model, they do not provide a formal test. Indeed, they could be driven by differences in firm characteristics, in survival rates across firms with different characteristics, or by time effects. To account for these possibilities, we now turn to explicit tests of the model's predictions.

\subsection{Cross-industry tests}

We start by testing Hypothesis 1: within firms, that is, after including firm fixed effects, leverage and maturity should be decreasing with age. This negative relation between age and both leverage and debt maturity should be stronger in industries with high set-up costs. Our main specification is as follows:

$$
\begin{aligned}
Y_{i j t}= & \beta_{0} \cdot \text { Age }_{i t}+\beta_{1} \cdot \text { Age }_{i t} \cdot \text { MidCost }_{i j}+\beta_{2} \cdot \text { Age }_{i t} \cdot \text { HighCost }_{i j} \\
& +\gamma_{3} \cdot \text { Controls }_{i t}+\nu_{i}+\lambda_{t}+\epsilon_{i j t},
\end{aligned}
$$


where $Y_{i j t}$ is either the leverage or the maturity of the debt of firm $i$ in industry $j$ in year $t$. Age $i$ is the age of firm $i$ in year $t$, while MidCost ${ }_{i j}$ and HighCost ${ }_{i j}$ are dummy variables equal to one for firm $i$ when its industry $j$ is in the middle or top tercile of the set-up cost distribution, respectively. Furthermore, a firm fixed effect $\nu_{i}$ ensures that we are exploiting within-firm variation, that is, our results cannot be explained by differential survival rates of firms across industries or by time-invariant differences across firms. To control for time-varying factors that could vary systematically across industries, we also include standard firm-level controls. Finally, $\lambda_{t}$ is a time fixed effect. Throughout the tests, we treat the set-up cost as a characteristic of the industry that is exogenous for any individual firm. Based on the model, we expect the baseline coefficient $\beta_{0}$ to be negative, and the interaction coefficient $\beta_{2}$ to also be negative: the effect of age on leverage and maturity should be larger in industries with high set-up costs.

The estimation results are reported in Table 3. We first confirm that, regardless of set-up costs, bank debt and maturity decrease with age, after including firm fixed effects. Therefore, our stylized facts are not driven by the selection of issuers with respect to age. In columns 2 and 6 , we find that the total effect is driven to a large extent by firms in high set-up cost industries, which is fully consistent with the model. In columns 3 and 7, we show that these results are robust to the inclusion of standard firm-level variables: asset size (in $\log$ ), as well as tangibility and profitability ratios. Finally, in columns 4 and 8, we keep only firms that survive at least 5 years, to further rule out concerns that survival biases could explain the findings. We find very similar coefficients. In the most demanding specifications, debt decreases on average by 1.2 percentage points per year of existence for firms in industries in the first tercile of set-up costs, and by 2.7 percentage points per year of existence in the last tercile. This is in line with the evolution reported in Figure 2, in which bank debt over total assets decreases by around 27 percentage points in ten years for firms in high set-up cost industries. As for maturity, every additional year of existence is associated with about a one-month decrease in the maturity of total debt for firms in high set-up cost industries. Again, this is consistent with, and even a bit stronger than the effect documented in Figure 2, in which the average debt maturity goes down by about 6 months for these firms between age 1 and age 10 .

The main concern with the previous results is that debt maturity could be mismeasured. Indeed, data from tax filings only measure debt maturity based on three buckets of maturity and our measure relies on the assumption that the average debt maturity in each of these buckets is constant across firms. Furthermore, these data measure the residual maturity of total debt (including trade credit), while the model's predictions pertain to the initial maturity of financial debt. We address these concerns by replicating some of the previous results using the loan-level data from M-Contran- 
in which we know the exact maturity of new bank loans granted to a sample of young firms for investment purposes.

First, consistent with the predictions of the model and the evidence we obtain when using accounting data, the last panel of Figure 2 confirms the finding that young firms borrow from banks at longer maturities than older firms. Unconditionally, a firm which is 4 years old borrows on average at a maturity that is 14 months shorter than a firm in its first year of existence. Also consistent with this stylized fact, the last panel of Figure 3 shows that this pattern is more pronounced for firms in high set-up cost industries. For example, the average loan maturity for firms in the top tercile of set-up costs decreases by 18 months over the first two years of existence of the firm, while it decreases by 10 to 15 months in the other two terciles.

Second, the regressions in Table 4 confirm that young firms in industries with high set-up costs tend to issue longer-maturity debt. In these regressions, we use the sample of loans made to new firms (with age equal to either 0 or 1 year, i.e. strictly below 24 months) to explain their maturity with a dummy for firms in industries with high set-up costs, after controlling for loan characteristics as well as quarter and bank fixed effects. The results in the first two columns show that young firms in high set-up cost industries borrow with longer maturities (by close to 8 months on average). In columns 3 and 4 of Table 4, we focus on the subsample of firms for which balance sheet data are available, which allows us to control for the same firm characteristics as above. ${ }^{14}$ Adding these standard firm-level controls yields very similar estimates, although the regression sample is now four and a half times smaller.

\subsection{Within-industry tests}

We next turn to Hypothesis 2. The prediction is that, within a given industry, young firms that are more financially constrained (that is, firms with low date- 1 cash flow $e$ ) opt for longer-maturity debt. We adopt the following specification:

$$
\text { Maturity }_{i j t}=\beta \cdot \frac{E B I T D A}{\text { Assets }}_{i j t}+\phi_{j}+\lambda_{t}+\epsilon_{i j t}
$$

where Maturity $_{i j t}$ is the debt maturity for firm $i$ operating in industry $j$ in year $t, \phi_{j}$ and $\lambda_{t}$ are industry and year fixed effects, respectively. As the empirical equivalent of the date- 1 cash flow $e$, we use the ratio of EBITDA over total assets. We restrict the sample to firms in their first two years here. Therefore, Equation (14) tests whether, for young firms within a given industry, a higher EBITDA is associated with longer or shorter-maturity debt. The model predicts that $\beta$ is negative.

\footnotetext{
${ }^{14}$ Due to the random selection of the reporting bank branches, our sample contains few young firms that receive multiple loans. This prevents us from including firm fixed effects in the tests that rely on these data.
} 
The estimation results are reported in Table 5. In the first two columns, we use the firm-level sample and the average maturity of total outstanding debt as a dependent variable, as in Table 3 above. Consistent with Hypothesis 2, we find in column 1 a negative and significant correlation of EBITDA with debt maturity, controlling for the average effect of belonging to a given industry and for macroeconomic conditions using year dummies, as well as for standard firm-level ratios. The results are roughly unchanged when we control for interacted industry and year fixed effects in the regression, as shown in column 2 .

In the last two columns of the same table we check that these results still hold when we use a finer measure of the maturity of bank debt and rely on loan-level data instead of firm-level data. As above in Table 4, we now consider the maturity at issuance of new bank loans as our dependent variable. In columns 3 and 4, we add bank fixed effects and we control for some loan characteristics (whether the loan is subsidized, has a fixed rate, or is regulated). Again, we find a confirmation that young firms that generate more cash flows tend to borrow at shorter maturities from their banks for investment purpose. This finding is also robust to the inclusion of more stringent set of fixed effects (here, interacted industry and quarter fixed effects, as the underlying data is at quarterly frequency). ${ }^{15}$ Economically, the impact on the maturity of new loans of a lower relative profitability within an industry is however smaller than the effect of belonging to a high-set-up-costs industry. Indeed, everything else equal, a young firm at the 25 th percentile of the profitability ratio issues new loans with a maturity shorter by about three months on average than a young firm at the 75 th percentile.

\subsection{Alternative mechanisms}

One potential alternative explanation for some of our results could be that firms with higher set-up costs buy assets with greater pledgeability, and so can borrow more and with longer-term debt, by using these assets as collateral. Our measure of set-up costs is correlated with firms' fixed assets, as discussed previously. However, although pleadgeability obviously bears upon debt capacity, it cannot be the main explanation behind our stylized facts. ${ }^{16}$ To begin with, pledgeability can explain differences in the average levels of debt and maturity (as seen from the sign of estimated coefficients on tangibility in Table 3), but not the time-series changes. Indeed, for tangibility to explain changes in maturity and leverage, it would have to be the case that tangibility decreases with age. We do not observe this to be the case: on average, firms in our

\footnotetext{
${ }^{15}$ The difference in the magnitude of coefficients between the two sets of columns in Table 5 is due to the fact that maturities are better measured in the second case. We measure the initial maturity of investment loans in columns 4-6, while in columns 1-3 the residual maturity of total debt on the balance sheet includes some forms of short-term debt (e.g., trade credit).

${ }^{16}$ For evidence on the relation between pledgeability and debt maturity or leverage, see for example Benmelech et al. (2005) and Benmelech (2009).
} 
sample invest every year to compensate the depreciation of assets. Furthermore, firms in our sample are on average growing with age. Therefore, the monotonic decrease in both leverage and debt maturity with age cannot be explained by tangibility. Furthermore, to alleviate remaining concerns, all our econometric results in Section 3.2 are robust to including measures of asset tangibility (PPE/Assets) as control variables, as seen in Table 3.

Another possible interpretation of our findings could be that the longer loan maturity of firms with higher set-up costs reflects the fact that their assets have a longer duration. If so, firms could match the maturity of cash flows from assets and liabilities, which could be valuable for risk management purposes (e.g., if they face financial constraints). This explanation would be consistent with our finding that firms in industries with high set-up costs, which also tend to be industries in which assets have longer duration, borrow at longer horizons. However, this explanation can be rejected for the exact same reason that led us to reject the alternative explanation based on tangibility. Specifically, for this explanation to be true, it would need to be the case that asset duration decreases monotonically with firm age. This is not the case due to the fact that firms periodically reinvest and replace maturing assets with other assets of similar duration. Therefore, the fact that we highlight does not stem from a property of the assets (which tend to remain similar over the life of a firm), but a property of the first few years. It is an "age effect" that is linked to set-up costs that are paid only once.

\section{Set-up costs and the transmission of financial shocks}

We now use a quasi-natural experiment to study the impact of set-up costs on the transmission of financial shocks.

\subsection{A quasi-natural experiment}

The shock we study arguably provides exogenous variation in the ability of some banks to supply long-term loans. In the context of the model, this corresponds to a drop in $\beta$. Our goal is to test whether firms in high set-up cost industries are affected differentially more.

The setup we use is the failure of the large Franco-Belgian bank Dexia in 2008. ${ }^{17}$ This bank was specialized in lending to local public administrations and local gov-

\footnotetext{
${ }^{17}$ The French public finance watchdog (Cour des comptes) published in 2013 a detailed report on the failure of Dexia. Statistics quoted in this section are taken from this report and from Dexia's annual reports over 2008-2012.
} 
ernments (called here "municipalities" for simplicity), with a market share of $40 \%$ in France. In 2008, Dexia was hit by severe credit losses in the US subprime market that were unrelated to French municipalities. ${ }^{18}$ It also had a fragile capital structure with a heavy reliance on wholesale funding. In October 2008, after the collapse of Lehman Brothers, Dexia was illiquid, forcing the French and Belgian governments to inject cash and to guarantee new bond issues. However, the bank never recovered and was dismantled in the winter 2012-2013. ${ }^{19}$ For our purposes, the key fact is that Dexia had to sharply reduce the supply of credit to municipalities starting in early 2008 (before the failure of Lehman Brothers) and until 2012. According to its annual reports, the annual lending volume of Dexia was cut by $50 \%$ between the end of 2007 and the end of 2010 .

We exploit the near failure of Dexia in 2008 as an exogenous event that affected differentially the ability of other French banks to accommodate the demand of longmaturity loans by firms. Our identification strategy proceeds in three steps. We first use data from the French credit register to identify municipalities that were highly dependent on Dexia before the start of the subprime crisis in August 2007. A municipality is defined in what follows as being Dexia-dependent whenever the share of Dexia in its total stock of bank debt in June 2007 (just before the subprime crisis) is above $50 \%$. This corresponds roughly to municipalities in the top quartile of the distribution of Dexia's market shares across all municipalities at this date.

In a second step, we classify commercial banks based on their share of loans to Dexia-dependent municipalities within their total lending to municipalities, also as of June 2007. Using this ratio, banks above the median are considered as treated by the Dexia shock in 2008. The underlying assumption is that municipalities that were relying heavily on Dexia are, after the Fall of 2008, forced to borrow more from other relationship lenders. These banks therefore face a positive loan demand shock, which they largely accommodate as we show below.

The third step of our identification strategy uses the fact that loans to municipalities have significantly longer maturities than loans to non-financial firms. In our data, on average over the sample period, the initial maturity of loans to municipalities is 13 years, as opposed to 6 years for non-financial firms. Therefore, the sudden increase in loans to municipalities by treated banks increases significantly the duration of their assets. Provided these banks have to meet risk management or regulatory limits in terms of asset-liability mismatch, their ability to supply long-term loans to companies should be reduced when they face higher loan demand from municipalities after the

\footnotetext{
${ }^{18}$ In addition to direct losses in the US subprime market, losses came from exposures to several European banks that were themselves hit by the US subprime market, and to the Financial Security Assurance (FSA), a monoline credit insurer that was a subsidiary of Dexia.

${ }^{19}$ The French part of its loan portfolio was acquired by three state-owned credit institutions, CDC, SFIL and La Banque Postale.
} 
Dexia shock. ${ }^{20}$ We confirm that this is the case in the next section.

One potential concern about this event is its timing. Since the near-failure of Dexia happens nearly at the time of the failure of Lehman Brothers, one may worry that treated and control banks are affected differentially by events unrelated to Dexia. However, given the methodology we use to construct the treatment, this is unlikely to be the case. Treated banks are identified by aggregating data from more than 36,000 French municipalities and other local governing councils. For the failure of Lehman Brothers to be a concern, it would need to be the case that some of these municipalities, the ones that depend more on Dexia for their funding, were more affected than others by the failure of Lehman Brothers. This is quite unlikely, especially since we observe no concentration of Dexia-dependent municipalities in specific regions.

To summarize, we exploit the near-failure of Dexia as an arguably exogenous shock to the supply of long-term credit to corporations by commercial banks. We define and use our treatment at three different levels in subsequent tests:

- At the municipality level: Treated (or "Dexia-dependent") municipalities are those for which the share of Dexia in the total stock of bank debt in June 2007 is above $50 \%$;

- At the bank level: Treated banks are those that have a share of loans to Dexiadependent municipalities within their total lending to municipalities above the median in June 2007;

- At the county level: Treated counties are those in which the share of treated banks (as defined above) in the total lending to corporations in the county is above the median in June 2007. We use this treatment in firm-level tests using Diane data, in which we use the information about the location of firms (i.e., the county in which they are located) but we do not know which banks firms borrow from.

\subsection{Relevance of the experiment}

In this section, we evaluate the relevance of the near-failure of Dexia as a potential exogenous shock to the supply of long-term credit of commercial banks, which could affect differentially firms in low- vs. high-set-up cost industries that have a different demand for long-term loans.

First, we compare treated and control banks. Table 6 gives reassurance that treated and control banks are not very different from each other: while they differ in terms

\footnotetext{
${ }^{20}$ Note that French banks were indeed subject to some national supervisory requirements in terms of their asset-liability liquidity ratios even before the progressive implementation of the Basel III liquidity coverage ratio (LCR) in the 2010 s.
} 
of their volume of loans to municipalities, they are quite similar in terms of the size of their loan portfolios to corporations. Beyond, both groupings include a significant number of both commercial and cooperative (or mutual) banks, as well as of specialized financial institutions. This suggests that the probability to be hit by the Dexia shock is a function of the geographical distribution of bank branches rather than a function of the type of the bank. Figure 4, which plots total cumulated lending to municipalities by treated vs control banks, confirms that treated banks increase relatively more their lending to municipalities after the shock: they indeed tend to accommodate the demand shock they face from Dexia-dependent municipalities. Specifically, we observe fairly parallel trends in credit to municipalities for the two groups of banks until early 2008, precisely when Dexia enters financial distress. After 2008, the patterns of municipal lending for treated and control banks diverge dramatically: between the end of 2007 and the end of 2009, credit to municipalities goes up by more than 10 percent for treated banks, while it increases by less than 5 percent for control banks. Then, it remains approximately flat for control banks, while it keeps growing for treated banks, to reach about 125 percent of the 2008 volume at the end of 2010.

In Table 7, we present regression results that further confirm the intuition behind our instrument. In all four columns, the dependent variable is the growth rate of bank loans to municipalities, as measured at the granular bilateral bank-municipality level. The time dimension is collapsed: we average outstanding bilateral credit amounts over two periods of two years before (2006Q3 to 2008Q2) and after (2008Q3 to 2010Q2) the treatment (the near failure of Dexia). We then compute growth rates between the two periods. These growth rates are regressed on a dummy variable equal to one for Dexia-dependent municipalities, i.e., municipalities with more than half of their bank debt coming from Dexia before the shock. The sample of banks excludes the Dexia group and the state-owned banks that acquired Dexia's municipal loans portfolio. All regressions include bank fixed effects, which allows to identify a demand shock by comparing municipalities borrowing from the same bank. We find that Dexia-dependent local public entities indeed increase their demand for commercial bank credit by about 7 percentage points on average after the shock. This extra demand for credit to commercial banks when Dexia reduces its activities is somewhat larger for groupings of cities (column 3) and municipal vehicles (column 4) than for municipalities strictly speaking (column 2).

For the treatment to affect the supply of long-term credit to corporations, banks affected by the Dexia shock have to reduce the maturity of corporate loans. Figure 5 provides a first indication that this is the case. It compares the average maturity of new loans to young firms (less than 24 months) across treated and control banks. Before 2008, we see no difference between the two groups of banks, while a gap appears around 2008, and closes only in 2012. The magnitude of the maturity difference is about 6 
months on average between 2008 and 2012. This first step confirms the relevance of our identification strategy: it is indeed the case that banks that make more long-term loans to municipalities following the near-failure of Dexia reduce the maturity of loans to corporations over the same period of time.

Next, we check whether this effect is stronger for firms in high set-up cost industries, which rely more on long-term debt. Figure 6 provides an unambiguous answer: the two upper panels replicate the same exercise as in Figure 5, after breaking down the sample between high and low set-up cost industries. We find that the drop in loan maturities following the Dexia shock affects only firms in industries with high set-up costs, that is, firms that belong to industries in the third tercile of the set-up cost distribution. Additionally, the bottom panels show that no such effect is observed on loan volumes: this means that we have isolated a shock that affects only loan maturity, which is exactly what is needed to test Hypothesis $3 .^{21}$

These effects are confirmed in difference-in-differences regressions at the loan level over the years 2006-2012, as shown in Table $8 .^{22}$ In specifications with loan-level controls as well as industry, county and time fixed effects (or even industry and county interacted with time), the treatment effect appears to be statistically significant at the $5 \%$ level: maturity-constrained banks indeed reduce the maturity of new corporate loans supplied to young firms by more than 3 months on average. The comparison of columns 3 and 4 shows that this effect is driven by firms in industries with high set-up costs, in which the average maturity drops by about four months for loans made by treated banks after the Dexia shock.

Finally, to better understand the mechanism at play, we additionally break down the sample between counties characterized by levels of bank competition above or below the median (based on the Herfindhal-Hirschmann index computed with local corporate loan shares). This allows us to address the concern that firms in high setup cost industries can obtain loans from control banks when treated banks cut the maturity of their corporate loans. In fact, this is true only for firms in areas with a high bank competition. In less competitive areas, the maturity constraint imposed by treated banks is likely to be more binding. In line with this intuition, comparing columns 5 and 6 shows that the maturity rationing effect is almost entirely explained by what happens in areas where the level of bank competition is low. In such local markets, the maturity of loans extended by treated banks to young firms in high set-up cost industries goes down by nearly 8 months after the Dexia shock. This is consistent with the intuition that, in areas where bank competition is weaker, local banks are

\footnotetext{
${ }^{21}$ Note that, unlike the evidence shown in table 7, this figure relates to the extensive margin of credit supply to young firms only.

${ }^{22}$ Tables A1 and A2 provide statistical evidence that loans supplied by the two types of banks, controls vs treated ones, are similar in terms of observables, a prerequisite for the validity of such tests.
} 
more able to unilaterally change the terms of the loans they make to corporations than when they face fiercer competition. In the Appendix Table A3, we confirm that the same drop in loan maturity is observed in the firm-level sample. ${ }^{23}$ As a last check, we ensure that the Dexia shocks affects primarily loan maturities rather than loan volumes. Specifically, in Appendix Table A4, we reproduce Table 8, but using the loan volume as dependent variable. We find no statistically significant effect of the Dexia shock on loan volumes.

\subsection{Real effects of maturity rationing}

Using the shock described above, we investigate whether maturity rationing by banks has consequences for young firms. The main prediction from our model is that, if young firms are denied long enough loan maturities by their banks, they may simply not start operating. Therefore, firms in industries that are particularly reliant on long-maturity debt should be more affected by a shock that affects the willingness of banks to make long-term loans. We investigate this prediction using data on the creation of all firms in France between 2006 and 2010. We identify firm creations at the county-industry level from Diane, which provides a comprehensive coverage of firms registered in France. ${ }^{24}$ Specifically, as a dependent variable, we use the logarithm of the number of firms created in a particular 3-digit industry in a given county and year. The Treated variable is constructed here at the county level, and corresponds to counties above the median in terms of the share of treated banks.

The baseline results are presented in Table 9. In the entire sample of treated counties, we observe a negative effect of the Dexia shock on firm creation in high set-up cost industries, albeit not statistically significant (column 1). When further breaking the sample between counties above or below the median in terms of lending competition, we find that the number of new firms entering high set-up cost industries drops by some $11 \%$ in treated counties after the shock when local bank competition is mild. This is consistent with the view that entrepreneurs in these areas face banks that are unwilling to extend long-maturity loans, and are unable to go to other banks, due to limited competition. This prediction is consistent with the model.

Finally, one may wonder whether the entire effect of maturity shortening by banks goes through firm creation or whether, even for firms that are created, a shorter maturity translates into lower growth in subsequent years (e.g., because some key investment needs to be postponed). Our model, which takes the initial investment size as fixed, predicts that the entire effect goes through reduced firm creation. However,

\footnotetext{
${ }^{23}$ Since we do not observe lenders in Diane, we construct a county-level measure of the treatment, as the market share of treated banks within the local market for corporate loans.

${ }^{24}$ These data normally suffer from a survivorship bias because Diane stops reporting any data for firms that have disappeared for more than three years. To deal with this issue, we obtained data from Diane about the firms that disappeared from their files between 2006 and 2016 .
} 
in a more general model with variable investment scale, firm size may also be affected, with firms in high set-up cost industries being created but at sizes below their optimum because of maturity constraints imposed by banks. To test whether this is the case, we estimate additional difference-in-differences models with measures of firm size after two years as dependent variables. First, we use our loan-level data and test whether borrowing a first loan from a treated bank reduces subsequent firm growth. Second, we use firm-level data and look at the effect on firm size of being located in a treated county. Whatever the specification, we do not find any significant effect of the Dexia shock on firm growth, even when restricting to low-competition counties. ${ }^{25}$ Our findings thus suggest that reduced firm creation is the main channel through which set-up costs affect the transmission of shocks in the economy.

\section{Conclusion}

Our main takeaway is that fixed set-up costs are essential to understand young firms. First, they explain otherwise puzzling features of their capital structure, both across and within industries. Most importantly, they explain why young firms borrow more, and with longer-maturity debt. Second, set-up costs explain the heterogeneous response of firms to some financing shocks. When lenders are forced to shrink the maturity of debt contracts, firms in industries characterized by high set-up costs are more affected.

The fact that young firms have a higher leverage and longer-term debt does not imply that there are no financial constraints. Indeed, these facts are conditional on firms being created. Instead, the model suggests that financial constraints operate via the selection of potential entrepreneurs into firm creation. In high set-up costs industries, the selection is tougher, and only the best-capitalized entrepreneurs are able to enter. Therefore, the fact that observed firms in these industries have high leverage and long-term debt is not a sign that financial constraints are absent, but a sign that many potential entrepreneurs are selected out of this industry, and thus unobserved.

These findings have important implications. First, they can help better design policies to foster firm creation. In particular, one cannot assume that all firms can start with arbitrarily small size and then grow. There are important "threshold effects" in firm creation. Policies that ignore this fact may end up helping only firms in low setup cost industries, which are the least constrained. Second, our results can help better understand recoveries following financial crises. If industries with high set-up costs are affected differentially more, then financial crises may be associated with long-lasting

\footnotetext{
${ }^{25}$ Detailed results are presented in Table A5 in the online appendix to save space, in Panel A for the loan-level regressions and in Panel B for the firm-level regressions.
} 
changes in industry composition. This prediction remains to be explored.

\section{References}

Albuquerque, R. and H. A. Hopenhayn (2004). Optimal lending contracts and firm dynamics. Review of Economic Studies 71, 285-315.

Almeida, H., M. Campello, B. Laranjeira, and S. Weisbenner (2012). Corporate debt maturity and the real effects of the 2007 credit crisis. Critical Finance Review 1, $3-58$.

Barclay, M. J. and C. W. Smith (1995). The maturity structure of corporate debt. Journal of Finance 50, 609-631.

Benmelech, E. (2009). Asset salability and debt maturity: Evidence from nineteenthcentury American railroads. Review of Financial Studies 22, 1545-1584.

Benmelech, E., M. J. Garmaise, and T. J. Moskowitz (2005). Do liquidation values affect financial contracts? Evidence from commercial loan contracts and zoning regulation. Quarterly Journal of Economics 120, 1121-1154.

Black, S. and P. Strahan (2002). Entrepreneurship and bank credit availability. Journal of Finance 57, 2807-2833.

Chodorow-Reich, G. (2014). The employment effects of credit market disruptions: Firm-level evidence from the 2008-09 financial crisis. Quarterly Journal of Economics 129, 1-59.

Cingano, F., F. Manaresi, and E. Sette (2016). Does credit crunch investment down? New evidence on the real effects of the bank-lending channel. Review of Financial Stuies 29, 2737-2773.

Custodio, C., M. A. Ferreira, and L. Laureano (2013). Why are US firms using more short-term debt? Journal of Financial Economics 108, 182-212.

Diamond, D. and Z. He (2014). A theory of debt maturity: The long and short of debt overhang. Journal of Finance 69, 719-762.

Diamond, D. W. (1991). Debt maturity structure and liquidity risk. Quarterly Journal of Economics 106, 709-737.

Dinlersoz, E., H. Hyatt, S. Kalemli-Ozcan, and V. Penciakova (2019). Leverage over the firm life cycle, firm growth, and aggregate fluctuations. FRB Atlanta Working Paper 2019-18, Federal Reserve Bank of Atlanta.

Evans, D. S. and L. S. Leighton (1989). Some empirical aspects of entrepreneurship. American Economic Review 79, 519-535. 
Guedes, J. and T. Opler (1996). The determinants of the maturity of corporate debt issues. Journal of Finance 51, 1809-1833.

He, Z. and K. Milbradt (2016). Dynamic debt maturity. Review of Financial Studies 29, 2677-2736.

He, Z. and W. Xiong (2012). Rollover risk and credit risk. Journal of Finance 67, 391-430.

Holmstrom, B. and J. Tirole (1997). Financial intermediation, loanable funds, and the real sector. Quarterly Journal of Economics 112, 663-691.

Huang, C., M. Oehmke, and H. Zhong (2019). A theory of multiperiod debt structure. Review of Financial Studies 32, 4447-4500.

Hurst, E. and A. Lusardi (2004). Liquidity constraints, household wealth, and entrepreneurship. Journal of Political Economy 112, 319-324.

Kerr, W. R. and R. Nanda (2015). Financing innovation. Annual Review of Financial Economics 7, 445-462.

Myers, S. (1977). Determinants of corporate borrowing. Journal of Financial Economics 5, 147-175.

Myers, S. C. and N. S. Majluf (1984). Corporate financing and investment decisions when firms have information that investors do not have. Journal of Financial Economics 13, 187-221.

Peek, J. and E. S. Rosengren (2000). Collateral damage: Effects of the Japanese bank crisis on real activity in the United States. American Economic Review 90, 30-45.

Rajan, R. G. and L. Zingales (1998). Financial dependence and growth. American Economic Review 88, 559-586.

Robb, A. M. and D. T. Robinson (2014). The capital structure decisions of new firms. Review of Financial Studies 27, 153-179.

Schmalz, M. C., D. A. Sraer, and D. Thesmar (2017). Housing collateral and entrepreneurship. Journal of Finance 72, 99-132.

Stiglitz, J. E. and A. Weiss (1981). Credit rationing in markets with imperfect information. American Economic Review 71, 393-410. 
Table 1: Descriptive statistics.

This table shows descriptive statistics in the pooled samples for the variables used in our analysis. Panel A is for the firm-level dataset (i.e., random $20 \%$ of the universe of firms created in France between 2006 and 2016). Panel B is for the loan-level dataset (survey of bank branches from 2006 to 2018), restricted to firms aged less than 24 months. Firms' total assets are expressed in thousand euros. The definition of the variables is provided in Appendix A.

\begin{tabular}{|c|c|c|c|c|c|c|c|c|}
\hline \multicolumn{9}{|c|}{ Panel A: Firm-level dataset } \\
\hline & Mean & St. dev. & p10 & $\mathrm{p} 25$ & Median & p75 & p90 & N. Obs. \\
\hline Size (log Assets) & 4.78 & 1.61 & 2.90 & 3.81 & 4.74 & 5.75 & 6.76 & 663,364 \\
\hline Age (in years) & 3.15 & 2.40 & 1 & 1 & 3 & 5 & 7 & 663,364 \\
\hline Total debt / Assets & 0.47 & 0.29 & 0.07 & 0.22 & 0.46 & 0.70 & 0.87 & 355,600 \\
\hline Financial debt / Assets & 0.30 & 0.28 & 0.00 & 0.04 & 0.22 & 0.52 & 0.75 & 358,803 \\
\hline Bank debt / Assets & 0.17 & 0.23 & 0 & 0 & 0.04 & 0.31 & 0.56 & 656,432 \\
\hline Other fin. debt / Assets & 0.13 & 0.19 & 0 & 0.00 & 0.04 & 0.18 & 0.40 & 367,262 \\
\hline Accounts payables / Assets & 0.16 & 0.17 & 0 & 0 & 0.10 & 0.23 & 0.41 & 655,040 \\
\hline Debt maturity (in months) & 18.11 & 10.49 & 12 & 12 & 12.60 & 20.45 & 30.46 & 255,950 \\
\hline Debt $\leq 1 \mathrm{y} /$ Debt & 0.57 & 0.42 & 0 & 0 & 0.71 & 1 & 1 & 358,768 \\
\hline Debt $>1 \mathrm{y}$ and $\leq 5 \mathrm{y} /$ Debt & 0.09 & 0.17 & 0 & 0 & 0 & 0.13 & 0.37 & 377,722 \\
\hline Debt $>5 y /$ Debt & 0.02 & 0.09 & 0 & 0 & 0 & 0 & 0.03 & 377,571 \\
\hline PPE / Assets & 0.15 & 0.21 & 0 & 0.00 & 0.06 & 0.20 & 0.45 & 378,681 \\
\hline Intangibles / Assets & 0.15 & 0.25 & 0 & 0 & 0.00 & 0.23 & 0.61 & 342,577 \\
\hline EBITDA / Assets & 0.10 & 0.16 & -0.08 & 0.01 & 0.10 & 0.19 & 0.30 & 328,806 \\
\hline
\end{tabular}

Panel B: Loan-level dataset (firms aged less than 24 months)

Loan characteristics

$\begin{array}{lcccccccc}\text { Initial maturity (in months) } & 71.14 & 27.56 & 36.00 & 60.00 & 84.00 & 84.00 & 86.00 & 37188 \\ \text { Loan amount (in thousand eu- } & 191.19 & 982.83 & 12.50 & 25.00 & 51.00 & 140.00 & 326.08 & 37188 \\ \text { ros) } & & & & & & & & \\ \text { Interest rate } & 3.27 & 1.49 & 1.17 & 1.97 & 3.40 & 4.40 & 5.15 & 37188 \\ \text { Subsidized loan } & 0.09 & 0.29 & 0.00 & 0.00 & 0.00 & 0.00 & 0.00 & 37188 \\ \text { Fixed rate loan } & 0.94 & 0.23 & 1.00 & 1.00 & 1.00 & 1.00 & 1.00 & 37188 \\ \text { Regulated loan } & 0.08 & 0.27 & 0.00 & 0.00 & 0.00 & 0.00 & 0.00 & 37188\end{array}$

Borrower characteristics

\begin{tabular}{lcccccccc} 
Size (log Assets) & 5.79 & 1.42 & 4.27 & 4.85 & 5.57 & 6.47 & 7.52 & 13504 \\
Age (in years) & 0.40 & 0.49 & 0.00 & 0.00 & 0.00 & 1.00 & 1.00 & 37188 \\
Standalone SME & 0.97 & 0.16 & 1.00 & 1.00 & 1.00 & 1.00 & 1.00 & 37188 \\
Financial debt / Assets & 0.57 & 0.26 & 0.20 & 0.37 & 0.60 & 0.78 & 0.89 & 8294 \\
PPE / Assets & 0.27 & 0.26 & 0.01 & 0.06 & 0.19 & 0.42 & 0.69 & 8788 \\
EBITDA / Assets & 0.05 & 0.18 & -0.13 & -0.02 & 0.05 & 0.15 & 0.26 & 8488 \\
\hline \hline
\end{tabular}


Table 2: Descriptive statistics on set-up costs

This table provides descriptive statistics on set-up costs, measured at the 3-digit industry level. Panel A displays moments of the cross-industry distribution of set-up costs. The measurement of industrylevel set-up costs is described in Section 2.2. Panel B shows the 15 industries with the lowest (left panel) and with the highest (right panel) set-up costs. Panel $\mathrm{C}$ regresses balance sheet characteristics at the firm-year level on a constant and on two dummies capturing whether the firm operates in an industry in the second (MidCost) or third (HighCost) tercile of the set-up cost distribution. The regressions are estimated in the sample of firms with age 0 or 1 (left lanel) and in the full sample of firms (right panel). Heteroskedasticity-robust standard errors are reported in brackets. ${ }^{*},{ }^{* *}$ and ${ }^{* * *}$ denote respectively statistical significance at the $10 \%, 5 \%$ and $1 \%$ levels.

\section{Panel A: Descriptive statistics}

$S U C_{i}$ (in thousand euros)

Mean 10th 25th 50th 75th 90th St. dev. N. Obs

Panel B: Industries with lowest and highest set-up costs

Top-15 lowest

\begin{tabular}{cc}
\hline 3-digit industry & $S U C_{i}$ \\
\hline Other civil engineering projects & 0 \\
Activities of head offices & 0 \\
Translation and interpretation activities & 0.6 \\
Other human resources provision & 0.7 \\
Management consultancy activities & 0.8 \\
Office administrative and support activities & 1.0 \\
Business support service activities & 1.1 \\
Other postal activities & 1.2 \\
Wholesale on a fee or contract basis & 1.4 \\
Other scientific and technical activities & 1.4 \\
Market research and public opinion polling & 1.7 \\
Non-specialised wholesale trade & 1.8 \\
Computer programming and related activities & 1.9 \\
Activities of employment placement agencies & 2.2 \\
Specialised design activities & 2.3
\end{tabular}

Top-15 highest

\begin{tabular}{cc}
\hline 3-digit industry & $S U C_{i}$ \\
\hline Fishing & 612.4 \\
Steam and air conditioning supply & 539.8 \\
Manufacture of paper products & 255.4 \\
Hotels and similar accommodation & 235.1 \\
Hospital activities & 220.4 \\
Manufacture of concrete products & 204.4 \\
Bakery & 192.7 \\
Veterinary activities & 188.1 \\
Sea and coastal passenger water transport & 181.5 \\
Medical and dental practice activities & 176.1 \\
Quarrying of stone, sand and clay & 155.4 \\
Dairy productions & 149.3 \\
Other retail sale in specialised stores & 148.4 \\
Camping grounds and trailer parks & 127.5 \\
Other human health activities & 121.0
\end{tabular}

Panel C: Set-up costs and balance sheet characteristics

\begin{tabular}{|c|c|c|c|c|c|c|}
\hline & \multicolumn{3}{|c|}{ Firms with age $<24$ months } & \multicolumn{3}{|c|}{ All firms } \\
\hline & $\begin{array}{l}\text { PPE } \\
\text { / Assets }\end{array}$ & $\begin{array}{c}\text { Intangibles } \\
\text { / Assets }\end{array}$ & Size & $\begin{array}{l}\text { PPE } \\
/ \text { Assets }\end{array}$ & $\begin{array}{c}\text { Intangibles } \\
\text { / Assets }\end{array}$ & Size \\
\hline Constant (LowCost) & $\begin{array}{c}0.076^{* * *} \\
{[0.001]}\end{array}$ & $\begin{array}{c}0.066^{* * *} \\
{[0.001]}\end{array}$ & $\begin{array}{c}4.116^{* * *} \\
{[0.006]}\end{array}$ & $\begin{array}{c}0.075^{* * *} \\
{[0.000]}\end{array}$ & $\begin{array}{c}0.065^{* * *} \\
{[0.000]}\end{array}$ & $\begin{array}{c}4.616^{* * *} \\
{[0.004]}\end{array}$ \\
\hline MidCost & $\begin{array}{c}0.112^{* * *} \\
{[0.002]}\end{array}$ & $\begin{array}{l}-0.000 \\
{[0.001]}\end{array}$ & $\begin{array}{c}0.081^{* * *} \\
{[0.008]}\end{array}$ & $\begin{array}{c}0.110^{* * *} \\
{[0.001]}\end{array}$ & $\begin{array}{l}0.001^{*} \\
{[0.001]}\end{array}$ & $\begin{array}{c}0.042^{* * *} \\
{[0.005]}\end{array}$ \\
\hline HighCost & $\begin{array}{c}0.163^{* * *} \\
{[0.001]}\end{array}$ & $\begin{array}{c}0.222^{* * *} \\
{[0.002]}\end{array}$ & $\begin{array}{c}0.649^{* * *} \\
{[0.008]}\end{array}$ & $\begin{array}{c}0.138^{* * *} \\
{[0.001]}\end{array}$ & $\begin{array}{c}0.243^{* * *} \\
{[0.001]}\end{array}$ & $\begin{array}{c}0.446^{* * *} \\
{[0.004]}\end{array}$ \\
\hline $\begin{array}{l}R^{2} \\
\text { N. Obs. }\end{array}$ & $\begin{array}{c}0.109 \\
105,287\end{array}$ & $\begin{array}{c}0.193 \\
97,549\end{array}$ & $\begin{array}{c}0.036 \\
204,052\end{array}$ & $\begin{array}{c}0.087 \\
378,681\end{array}$ & $\begin{array}{c}0.215 \\
342,577\end{array}$ & $\begin{array}{c}0.016 \\
663,364\end{array}$ \\
\hline
\end{tabular}


Table 3: The role of set-up costs across industries - Using firm-level data

This table provides estimates of Equation (13), using either bank debt over total assets or the residual maturity of total debt (measured in months) as dependent variables. MidCost and HighCost are dummy variables equal to one for firms in 3-digit industries that are respectively in the middle and top terciles of the set-up cost distribution. The estimation is conducted in the pooled sample of Diane firms. The definition of the variables is provided in Appendix A. Standard errors, clustered at the firm level, are reported in brackets. ${ }^{*},{ }^{* *}$ and ${ }^{* * *}$ denote respectively statistical significance at the $10 \%, 5 \%$ and $1 \%$ levels.

\begin{tabular}{|c|c|c|c|c|c|c|c|c|}
\hline \multirow[b]{3}{*}{ Age } & \multicolumn{8}{|c|}{ Dependent variable: } \\
\hline & & Bank deb & t / Assets & & Maturi & ity of total & l debt (in & months) \\
\hline & $\begin{array}{c}-0.015^{* * *} \\
{[0.000]}\end{array}$ & $\begin{array}{c}-0.004^{* * *} \\
{[0.000]}\end{array}$ & $\begin{array}{c}-0.012^{* * *} \\
{[0.000]}\end{array}$ & $\begin{array}{c}-0.012^{* * *} \\
{[0.000]}\end{array}$ & $\begin{array}{c}-0.575^{* * *} \\
{[0.021]}\end{array}$ & $\begin{array}{c}-0.273^{* * *} \\
{[0.023]}\end{array}$ & $\begin{array}{c}-0.599^{* * *} \\
{[0.027]}\end{array}$ & $\begin{array}{c}-0.591^{* * *} \\
{[0.029]}\end{array}$ \\
\hline Age $\times$ MidCost & & $\begin{array}{c}-0.002^{* * *} \\
{[0.000]}\end{array}$ & $\begin{array}{c}0.001^{* * *} \\
{[0.000]}\end{array}$ & $\begin{array}{c}0.000^{* *} \\
{[0.000]}\end{array}$ & & $\begin{array}{c}0.143^{* * *} \\
{[0.029]}\end{array}$ & $\begin{array}{c}0.223^{* * *} \\
{[0.029]}\end{array}$ & $\begin{array}{c}0.221^{* * *} \\
{[0.030]}\end{array}$ \\
\hline Age $\times$ HighCost & & $\begin{array}{c}-0.026^{* * *} \\
{[0.000]}\end{array}$ & $\begin{array}{c}-0.015^{* * *} \\
{[0.000]}\end{array}$ & $\begin{array}{c}-0.019^{* * *} \\
{[0.001]}\end{array}$ & & $\begin{array}{c}-0.927^{* * *} \\
{[0.026]}\end{array}$ & $\begin{array}{c}-0.599^{* * *} \\
{[0.029]}\end{array}$ & $\begin{array}{c}-0.570^{* * *} \\
{[0.030]}\end{array}$ \\
\hline Size & & & $\begin{array}{c}0.038^{* * *} \\
{[0.001]}\end{array}$ & $\begin{array}{c}0.040^{* * *} \\
{[0.001]}\end{array}$ & & & $\begin{array}{c}2.133^{* * *} \\
{[0.069]}\end{array}$ & $\begin{array}{c}2.221^{* * *} \\
{[0.078]}\end{array}$ \\
\hline PPE / Assets & & & $\begin{array}{c}0.389^{* * *} \\
{[0.005]}\end{array}$ & $\begin{array}{c}0.391^{* * *} \\
{[0.007]}\end{array}$ & & & $\begin{array}{c}14.169^{* * *} \\
{[0.405]}\end{array}$ & $\begin{array}{c}14.466^{* * *} \\
{[0.463]}\end{array}$ \\
\hline EBITDA / Assets & & & $\begin{array}{c}-0.102^{* * *} \\
{[0.002]}\end{array}$ & $\begin{array}{c}-0.103^{* * *} \\
{[0.002]}\end{array}$ & & & $\begin{array}{c}-1.882^{* * *} \\
{[0.131]}\end{array}$ & $\begin{array}{c}-2.017^{* * *} \\
{[0.158]}\end{array}$ \\
\hline Survival $\geq 5 \mathrm{y}$. & No & No & No & Yes & No & No & No & Yes \\
\hline Firm FE & Yes & Yes & Yes & Yes & Yes & Yes & Yes & Yes \\
\hline Year FE & Yes & Yes & Yes & Yes & Yes & Yes & Yes & Yes \\
\hline Observations & 656,432 & 656,432 & 327,128 & 227,832 & 255,950 & 255,950 & 223,946 & 158,817 \\
\hline Within- $R^{2}$ & 0.073 & 0.118 & 0.265 & 0.283 & 0.032 & 0.060 & 0.135 & 0.143 \\
\hline
\end{tabular}


Table 4: The role of set-up costs across industries - Using loan-level data

This table provides estimates of Equation (13) using loan-level data from $M$-Contran. The dependent variable is the initial maturity of new loans, measured in months. MidCost and HighCost are dummy variables equal to one for firms in 3-digit industries that are respectively in the middle and top terciles of the set-up cost distribution. The estimation is conducted in the sample of firms with age below 24 months. Columns 1 and 2 use the whole sample of borrowing firms, while columns 3 and 4 restrict the estimation sample to firms with available balance sheet data. The definition of the variables is provided in Appendix A. Standard errors, clustered at the 3-digit industry level, are reported in brackets. ${ }^{*},{ }^{* *}$ and ${ }^{* * *}$ denote respectively statistical significance at the $10 \%, 5 \%$ and $1 \%$ levels.

\begin{tabular}{|c|c|c|c|c|}
\hline & \multicolumn{4}{|c|}{ Dependent variable: Initial maturity of new loans } \\
\hline & \multicolumn{2}{|c|}{ All firms } & \multicolumn{2}{|c|}{$\begin{array}{c}\text { Firms with } \\
\text { balance sheets }\end{array}$} \\
\hline & (1) & $(2)$ & (3) & (4) \\
\hline HighCost & $\begin{array}{c}7.761^{* * *} \\
{[2.577]}\end{array}$ & $\begin{array}{c}7.592^{* * *} \\
{[2.616]}\end{array}$ & $\begin{array}{l}7.727^{* *} \\
{[3.302]}\end{array}$ & $\begin{array}{l}7.863^{* *} \\
{[3.807]}\end{array}$ \\
\hline MidCost & $\begin{array}{l}-3.441 \\
{[3.763]}\end{array}$ & $\begin{array}{l}-3.573 \\
{[3.847]}\end{array}$ & $\begin{array}{l}-4.121 \\
{[4.619]}\end{array}$ & $\begin{array}{l}-2.116 \\
{[3.888]}\end{array}$ \\
\hline Subsidized loan & & $\begin{array}{c}5.587^{* * *} \\
{[0.594]}\end{array}$ & $\begin{array}{c}2.452 \\
{[1.532]}\end{array}$ & $\begin{array}{l}3.159^{* *} \\
{[1.457]}\end{array}$ \\
\hline Fixed rate loan & & $\begin{array}{l}1.818 \\
{[2.517]}\end{array}$ & $\begin{array}{l}-0.382 \\
{[3.850]}\end{array}$ & $\begin{array}{l}5.631 \\
{[3.638]}\end{array}$ \\
\hline Regulated loan & & $\begin{array}{c}-4.528^{* * *} \\
{[1.262]}\end{array}$ & $\begin{array}{l}-3.108 \\
{[1.886]}\end{array}$ & $\begin{array}{l}-3.234^{*} \\
{[1.808]}\end{array}$ \\
\hline Size & & & & $\begin{array}{c}3.953^{* * *} \\
{[1.133]}\end{array}$ \\
\hline PPE / Assets & & & & $\begin{array}{c}9.076 \\
{[7.352]}\end{array}$ \\
\hline EBITDA / Assets & & & & $\begin{array}{c}-19.464^{* * *} \\
{[2.590]}\end{array}$ \\
\hline Quarter FE & Yes & Yes & Yes & Yes \\
\hline Bank FE & Yes & Yes & Yes & Yes \\
\hline $\mathrm{Nb}$ clusters & 129 & 129 & 125 & 126 \\
\hline Observations & 37,180 & 37,180 & 8,013 & 8,473 \\
\hline Adj. $R^{2}$ & 0.09 & 0.09 & 0.13 & 0.17 \\
\hline
\end{tabular}


Table 5: Within-industry tests: the role of cash flow

This table provides the estimates of Equation (14), using the residual maturity of total debt from the firm-level sample (columns 1-2) and the initial maturity of new loans from the loan-level sample (columns 3-4) as dependent variables. The estimation is conducted on the sample of firms with age below 24 months over the 2006-2018 period. The definition of the variables is provided in Appendix A. Time fixed effects refer to yearly dummies in the first two columns, and to quarterly dummies in the last two. Standard errors, clustered at the firm level in columns 1-2 and at the 3-digit industry level in columns $3-4$, are reported in brackets. ${ }^{*},{ }^{* *}$ and ${ }^{* * *}$ denote respectively statistical significance at the $10 \%, 5 \%$ and $1 \%$ levels.

\begin{tabular}{|c|c|c|c|c|}
\hline & \multicolumn{2}{|c|}{ Maturity of total debt } & \multicolumn{2}{|c|}{$\begin{array}{l}\text { Initial maturity } \\
\text { of new loans }\end{array}$} \\
\hline & (1) & (2) & (3) & (4) \\
\hline EBITDA / Assets & $\begin{array}{c}-2.575^{* * *} \\
{[0.208]}\end{array}$ & $\begin{array}{c}-2.550^{* * *} \\
{[0.210]}\end{array}$ & $\begin{array}{c}-15.542^{* * *} \\
{[2.206]}\end{array}$ & $\begin{array}{c}-19.183^{* * *} \\
{[3.173]}\end{array}$ \\
\hline Subsidized loan & & & $\begin{array}{c}3.630^{* * *} \\
{[1.298]}\end{array}$ & $\begin{array}{c}4.758^{* * *} \\
{[0.934]}\end{array}$ \\
\hline Fixed rate loan & & & $\begin{array}{l}6.422^{*} \\
{[3.250]}\end{array}$ & $\begin{array}{l}3.869 \\
{[2.914]}\end{array}$ \\
\hline Regulated loan & & & $\begin{array}{l}-2.185 \\
{[1.437]}\end{array}$ & $\begin{array}{l}-2.633 \\
{[1.840]}\end{array}$ \\
\hline Size & $\begin{array}{c}1.993^{* * *} \\
{[0.039]}\end{array}$ & $\begin{array}{c}2.021^{* * *} \\
{[0.039]}\end{array}$ & $\begin{array}{l}3.044^{* *} \\
{[1.303]}\end{array}$ & $\begin{array}{l}4.055^{* * *} \\
{[1.496]}\end{array}$ \\
\hline PPE / Assets & $\begin{array}{c}9.277^{* * *} \\
{[0.294]} \\
\end{array}$ & $\begin{array}{c}9.195^{* * *} \\
{[0.292]} \\
\end{array}$ & $\begin{array}{c}5.141 \\
{[4.484]}\end{array}$ & $\begin{array}{c}3.874 \\
{[5.178]} \\
\end{array}$ \\
\hline Bank FE & - & - & Yes & Yes \\
\hline Industry FE & Yes & No & Yes & No \\
\hline Time FE & Yes & No & Yes & No \\
\hline Industry $\times$ Year FE & No & Yes & No & Yes \\
\hline Observations & 58,957 & 58,830 & 8,469 & 7,482 \\
\hline Adj. $R^{2}$ & 0.29 & 0.31 & 0.27 & 0.36 \\
\hline
\end{tabular}


Table 6: Comparison of treated and control banks

This table compares the loan volume of treated and control banks, as defined in Section 4.1. The loan volumes are computed before the treatment by the Dexia shock, as averages over the period from 2006Q3 to 2008Q2. We further break down total loan volumes between loans to municipalities and loans to corporations. Loan volumes are expressed in million euros.

\begin{tabular}{|c|c|c|c|c|c|c|}
\hline & N. Obs. & Mean & St. dev. & p25 & Median & p75 \\
\hline \multicolumn{7}{|c|}{ Control banks } \\
\hline Muni. loans (EUR mns) & 104 & 305.59 & 1035.98 & 0.80 & 5.71 & 274.41 \\
\hline Corp. loans (EUR mns) & 104 & 1557.52 & 4910.46 & 123.62 & 362.95 & 1206.84 \\
\hline Commercial bank & 102 & 0.34 & 0.48 & 0.00 & 0.00 & 1.00 \\
\hline Cooperative bank & 102 & 0.36 & 0.48 & 0.00 & 0.00 & 1.00 \\
\hline Fin. company & 102 & 0.07 & 0.25 & 0.00 & 0.00 & 0.00 \\
\hline Specialized credit inst. & 102 & 0.21 & 0.41 & 0.00 & 0.00 & 0.00 \\
\hline Foreign institution & 102 & 0.00 & 0.00 & 0.00 & 0.00 & 0.00 \\
\hline \multicolumn{7}{|c|}{ Treated banks } \\
\hline Muni. loans (EUR mns) & 104 & 532.39 & 1423.23 & 5.09 & 143.95 & 689.73 \\
\hline Corp. loans (EUR mns) & 104 & 1627.82 & 4241.74 & 223.13 & 648.37 & 1347.57 \\
\hline Commercial bank & 104 & 0.19 & 0.40 & 0.00 & 0.00 & 0.00 \\
\hline Cooperative bank & 104 & 0.65 & 0.48 & 0.00 & 1.00 & 1.00 \\
\hline Fin. company & 104 & 0.01 & 0.10 & 0.00 & 0.00 & 0.00 \\
\hline Specialized credit inst. & 104 & 0.13 & 0.34 & 0.00 & 0.00 & 0.00 \\
\hline Foreign institution & 104 & 0.01 & 0.10 & 0.00 & 0.00 & 0.00 \\
\hline \multicolumn{7}{|c|}{ All banks } \\
\hline Muni. loans (EUR mns) & 208 & 418.99 & 1246.94 & 1.88 & 29.89 & 535.28 \\
\hline Corp. loans (EUR mns) & 208 & 1592.67 & 4577.34 & 151.66 & 503.23 & 1287.55 \\
\hline Commercial bank & 206 & 0.27 & 0.44 & 0.00 & 0.00 & 1.00 \\
\hline Cooperative bank & 206 & 0.51 & 0.50 & 0.00 & 1.00 & 1.00 \\
\hline Fin. company & 206 & 0.04 & 0.19 & 0.00 & 0.00 & 0.00 \\
\hline Specialized credit inst. & 206 & 0.17 & 0.38 & 0.00 & 0.00 & 0.00 \\
\hline Foreign institution & 206 & 0.00 & 0.07 & 0.00 & 0.00 & 0.00 \\
\hline
\end{tabular}


Table 7: Loan growth after the Dexia shock

This table regresses the log growth of average bilateral bank-borrower credit amounts between 2006Q3-2008Q2 and 2008Q3-2010Q2. Dexia and three state-owned banks are excluded from the sample of banks. In columns 1 to 4 , borrowers are municipalities. Treated municipalities are municipalities which were Dexia-dependent before the shock. Treated banks are banks whose municipal lending was tilted towards "treated" municipalities before the shock. In some specifications, we use the log volume of corporate loan books as controls for bank size (as averages over the period from 2006Q3 to 2008Q2). The definition of the variables is provided in Appendix A. Robust standard errors are reported in brackets. ${ }^{*},{ }^{* *}$ and ${ }^{* * *}$ denote respectively statistical significance at the $10 \%$, $5 \%$ and $1 \%$ levels.

\begin{tabular}{lcccc}
\hline \hline & \multicolumn{4}{c}{ Municipalities } \\
\cline { 2 - 5 } & $(1)$ & $(2)$ & $(3)$ & $(4)$ \\
& All & Cities & City group. & Municip. vehic. \\
\hline Treated municip. & $0.070^{* * *}$ & $0.067^{* * *}$ & $0.091^{* * *}$ & $0.080^{* * *}$ \\
& {$[0.006]$} & {$[0.007]$} & {$[0.022]$} & {$[0.020]$} \\
\hline Bank FE & Yes & Yes & Yes & Yes \\
Observations & 39,090 & 29,364 & 3,703 & 4,709 \\
Adj. R2 & 0.04 & 0.05 & 0.04 & 0.02 \\
\hline \hline
\end{tabular}


Table 8: Maturity of new loans to young firms after the Dexia shock

This table estimates a difference-in-differences model with the initial maturity of new loans to young non-financial firms (below 24 months) as dependent variable, using the loan-level sample. The treatment is defined at the bank level, as described in Section 4.1. In sum, a bank is treated by the Dexia shock if it is highly exposed to municipalities borrowing heavily from Dexia before 2008. 3-digit industries with low and high set-up costs (SUC) are respectively industries in the bottom and the top tercile of the set-up cost distribution. Loan-level controls are dummy variables for subsidized, fixed rate and regulated loans respectively. Counties with high bank competition are counties with an Herfindhal-Hirschmann index (computed based on banks' local corporate loan shares as of 2007) below the median. The estimation period is from 2006 to 2012. Period fixed effects are dummy variables for the two time periods before and after the Dexia shock of 2008 Q3. Standard errors are clustered at the bank level and are reported in brackets. ${ }^{*},{ }^{* *}$ and ${ }^{* * *}$ denote respectively statistical significance at the $10 \%, 5 \%$ and $1 \%$ levels.

\begin{tabular}{|c|c|c|c|c|c|c|}
\hline & \multicolumn{6}{|c|}{ Dependent variable: Initial maturity of new loans } \\
\hline & \multicolumn{2}{|c|}{ All $<24 m$} & \multirow[t]{2}{*}{ Low SUC } & \multicolumn{3}{|c|}{ High SUC } \\
\hline & & & & & $\begin{array}{c}\text { Low } \\
\text { competition }\end{array}$ & $\begin{array}{c}\text { High } \\
\text { competition }\end{array}$ \\
\hline \multirow[t]{2}{*}{ Treated bank $\times$ Post } & $-3.084^{* *}$ & $-3.243^{* *}$ & -1.615 & $-4.080^{* *}$ & $-7.821^{* * *}$ & -2.296 \\
\hline & {$[1.346]$} & {$[1.404]$} & {$[3.117]$} & {$[1.797]$} & {$[2.809]$} & {$[1.861]$} \\
\hline \multirow[t]{2}{*}{ Treated bank } & -2.225 & -2.019 & -1.454 & -1.545 & 2.069 & -3.011 \\
\hline & {$[1.673]$} & {$[1.730]$} & {$[2.449]$} & {$[2.103]$} & {$[2.122]$} & {$[2.415]$} \\
\hline \multirow[t]{2}{*}{ Constant } & $66.555^{* * *}$ & $67.127^{* * *}$ & $58.165^{* * *}$ & $68.568^{* * *}$ & $63.759^{* * *}$ & $70.931^{* * *}$ \\
\hline & {$[4.403]$} & {$[4.092]$} & {$[3.481]$} & {$[5.745]$} & {$[4.134]$} & {$[6.337]$} \\
\hline Industry FE & Yes & No & Yes & Yes & Yes & Yes \\
\hline Quarter FE & Yes & Yes & Yes & Yes & Yes & Yes \\
\hline County FE & Yes & No & Yes & Yes & Yes & Yes \\
\hline Indus. $\times$ Period FE & No & Yes & No & No & No & No \\
\hline County $\times$ Period FE & No & Yes & No & No & No & No \\
\hline Loan controls & Yes & Yes & Yes & Yes & Yes & Yes \\
\hline $\mathrm{Nb}$ clust & 163 & 163 & 138 & 147 & 108 & 143 \\
\hline Observations & 20,288 & 20,282 & 2,996 & 12,367 & 3,243 & 9,122 \\
\hline Adj. R2 & 0.16 & 0.17 & 0.08 & 0.08 & 0.11 & 0.09 \\
\hline
\end{tabular}


Table 9: Firm creation after the Dexia shock

This tables estimates a difference-in-differences model with the log nomber of firms created as dependent variable. The treatment is defined at the county level. A county is treated by the Dexia shock if banks that lend heavily to Dexia-exposed municipalities before 2008 have a large market share (i.e., above the median across counties). 3-digit industries with low and high set-up costs (SUC) are respectively industries in the bottom and the top tercile of the set-up cost distribution. Standard errors are reported in brackets. ${ }^{*},{ }^{* *}$ and ${ }^{* * *}$ denote respectively statistical significance at the $10 \%$, $5 \%$ and $1 \%$ levels.

\begin{tabular}{lcccc}
\hline \hline & \multicolumn{3}{c}{$\begin{array}{c}\text { Dependent variable: } \\
\text { Firm creation (in log) }\end{array}$} \\
\cline { 2 - 5 } & \multicolumn{3}{c}{ All } & Low comp. High comp. \\
\hline Treated county $\times$ Post $\times$ HighCost & -0.034 & $-0.113^{*}$ & 0.016 \\
Treated $\times$ HighCost & {$[0.047]$} & {$[0.059]$} & {$[0.067]$} \\
& $0.051^{*}$ & $0.078^{* *}$ & 0.030 \\
Post $\times$ HighCost & {$[0.030]$} & {$[0.037]$} & {$[0.042]$} \\
HighCost & 0.043 & 0.064 & 0.030 \\
& {$[0.034]$} & {$[0.043]$} & {$[0.047]$} \\
Within- $R^{2}$ & $0.060^{* * *}$ & $0.092^{* * *}$ & 0.041 \\
County*Period FE & {$[0.021]$} & {$[0.027]$} & {$[0.030]$} \\
N. Obs & 0.121 & 0.048 & 0.078 \\
\hline \hline
\end{tabular}




\section{Figure 1: Model dynamics}

This figure summarizes the model dynamics, using a baseline calibration with $\underline{A}=0, \bar{A}=9, I=10$, $\beta=1, p_{H}=0.7, p_{L}=0.5, R=12, B=2, e=3$, and a uniform distribution $g$ of net worth. Panel A studies the share of debt repayment made at date 2 , as a function of net worth $A$, for low and high set-up cost industries ( $I=7$ and $I=10$ respectively). Panel B studies the share of external financing as a function of net worth, for low and high set-up cost industries ( $I=7$ and $I=10$ respectively). Panel $\mathrm{C}$ studies the share of debt repayment made at date 2, as a function of net worth $A$, for low and high profitability firms ( $e=3$ and $e=6$ respectively). Panel D studies the share of funded projects as a function of lenders' discount factor $\beta$, for low and high set-up cost industries $(I=7$ and $I=10$ respectively). In Panels A, B, and $\mathrm{C}$, vertical lines represent the threshold $A^{*}(I, \beta)$ below which firms do not obtain financing.

Panel A

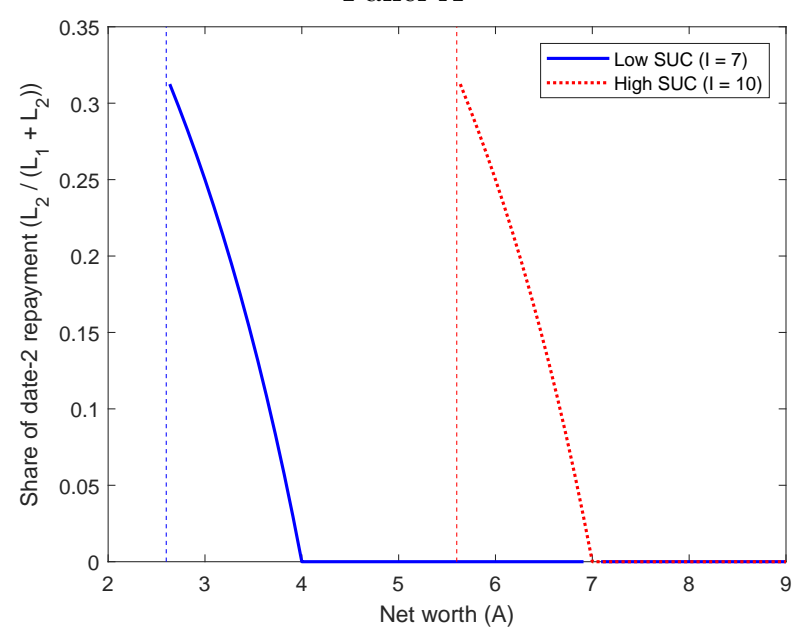

Panel C

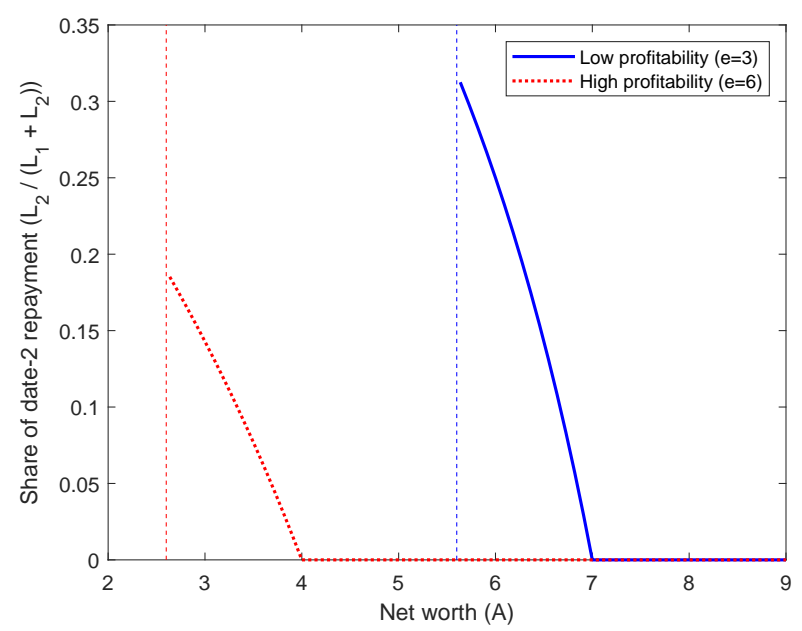

Panel B

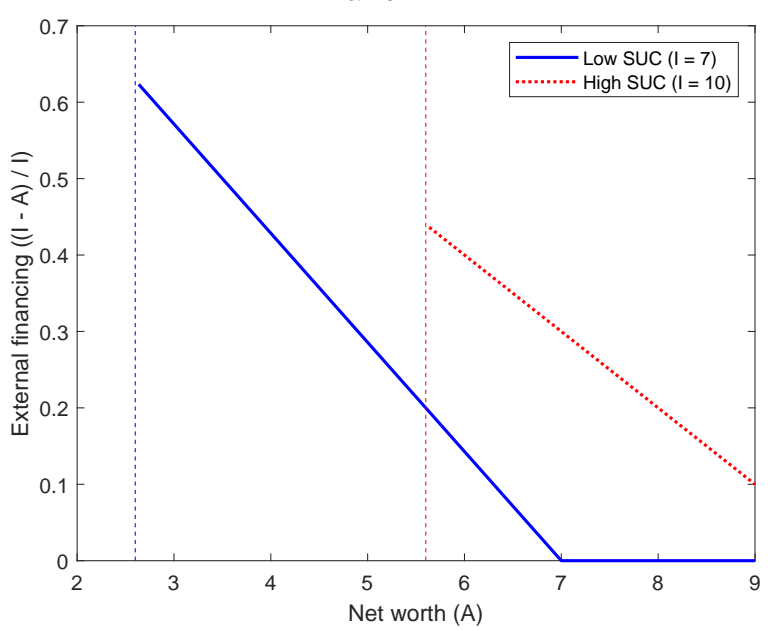

Panel D

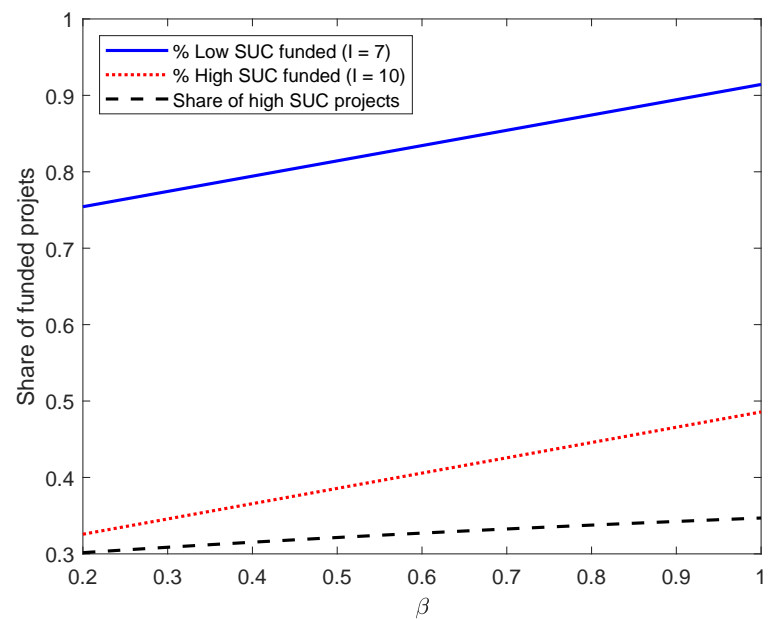


Figure 2: Stylized facts - Pooled sample: balance sheet structure

This figure plots stylized facts about the capital structure of firms between their creation and age 10 . Each line is obtained by computing the mean of the relevant variable in the pooled sample of Diane firms. Total debt is defined to include both financial debt (from banks or other lenders, including family and friends) and payables. In the first five panels, the data are from Diane and the maturity of debt is the residual maturity of total debt. In the last panel, the exact maturity of bank loans is measured from M-Contran.

Total debt / Assets

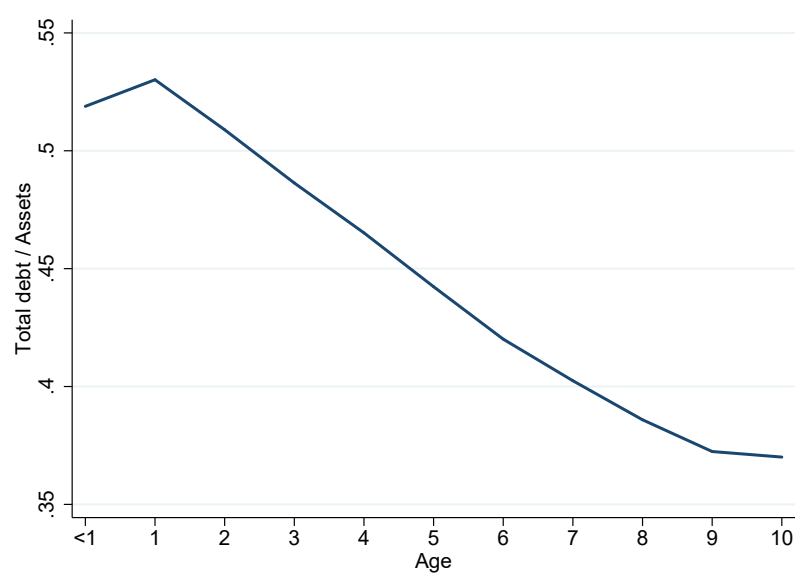

Bank debt / Assets

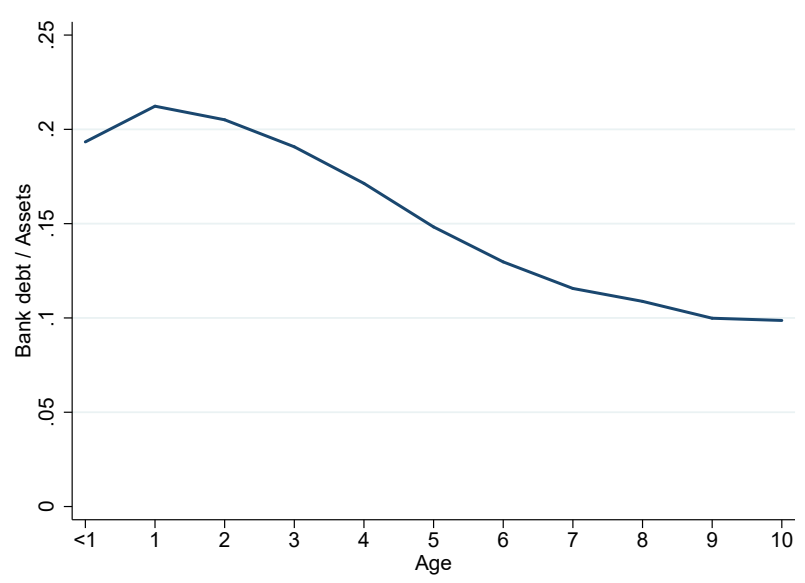

Payables / Assets

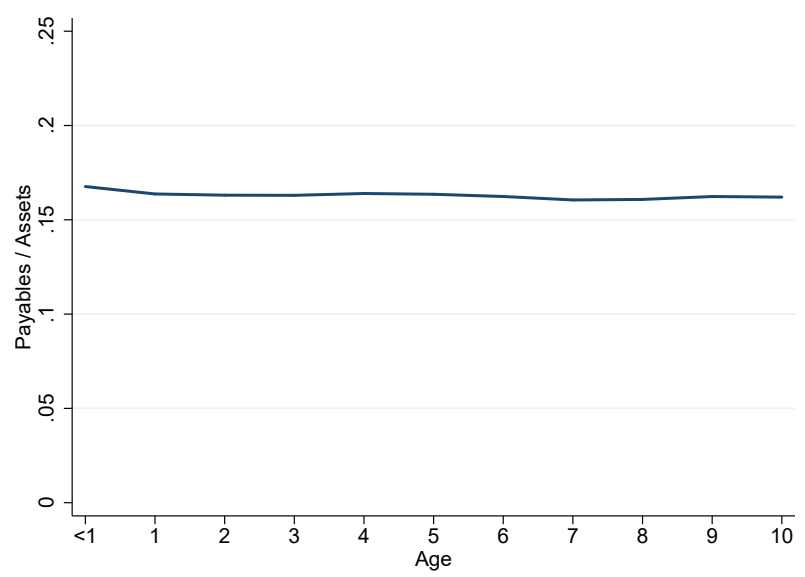

Maturity of total debt (in months)

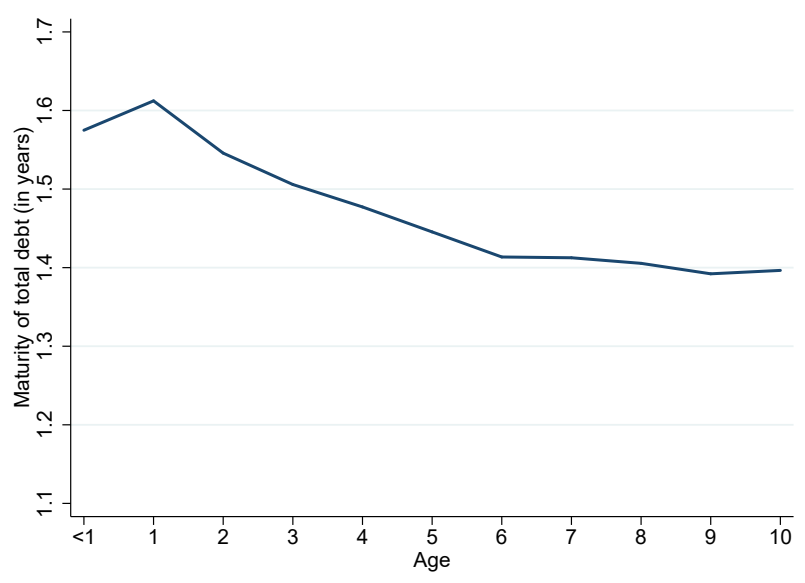

Other financial debt / Assets

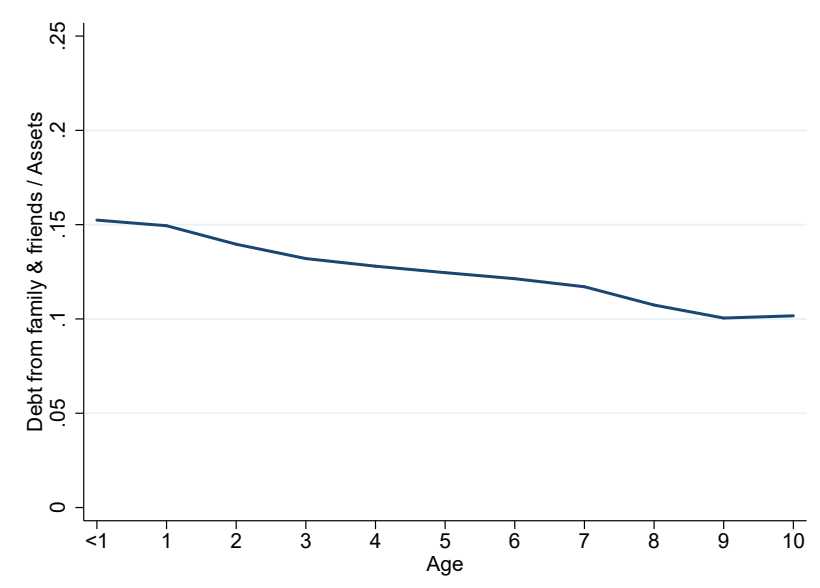

Initial maturity of bank debt (in months)

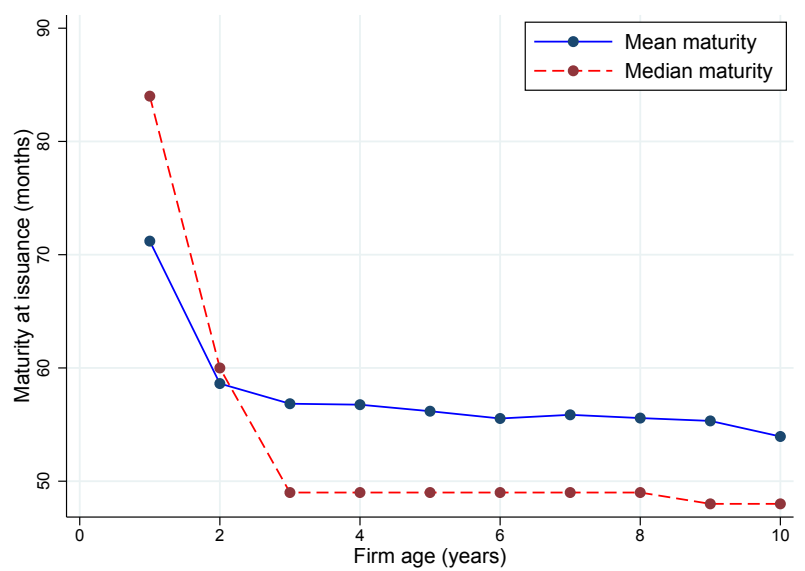


Figure 3: Stylized facts - By set-up cost terciles: balance sheet structure

This figure plots stylized facts about the capital structure of firms between their creation and age 10 . Each line is obtained by computing the mean of the relevant variable for all firms in each tercile of the measure of set-up cost. Set-up costs are computed at the 3-digit industry level using the procedure described in Section 2.2. Total debt is defined to include both financial debt (from banks or other lenders, including family and friends) and payables. In the first five panels, the data are from Diane and the maturity of debt is the residual maturity of total debt. In the last panel, the exact maturity of bank loans is measured from M-Contran.

Total debt / Assets

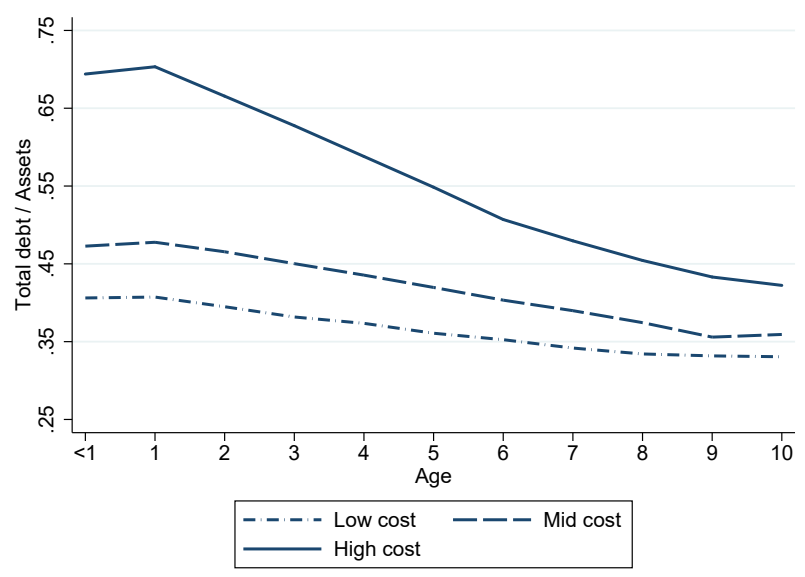

Bank debt / Assets

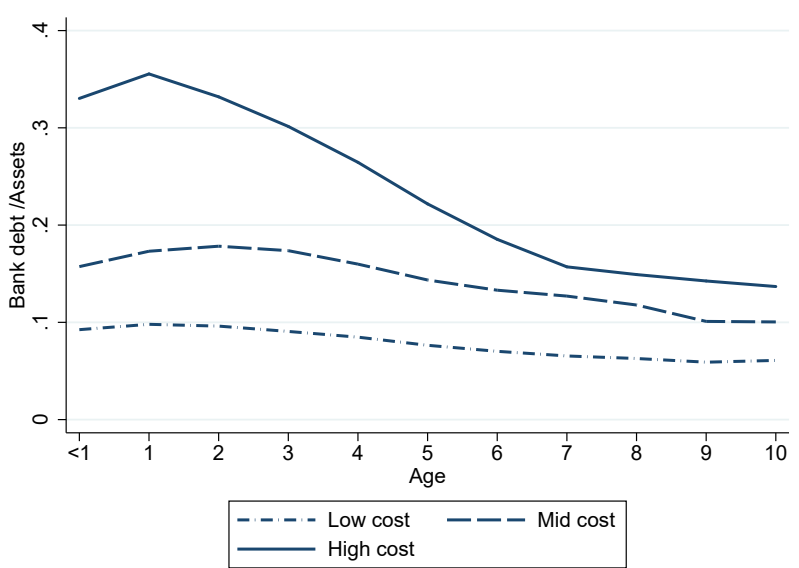

Payables / Assets

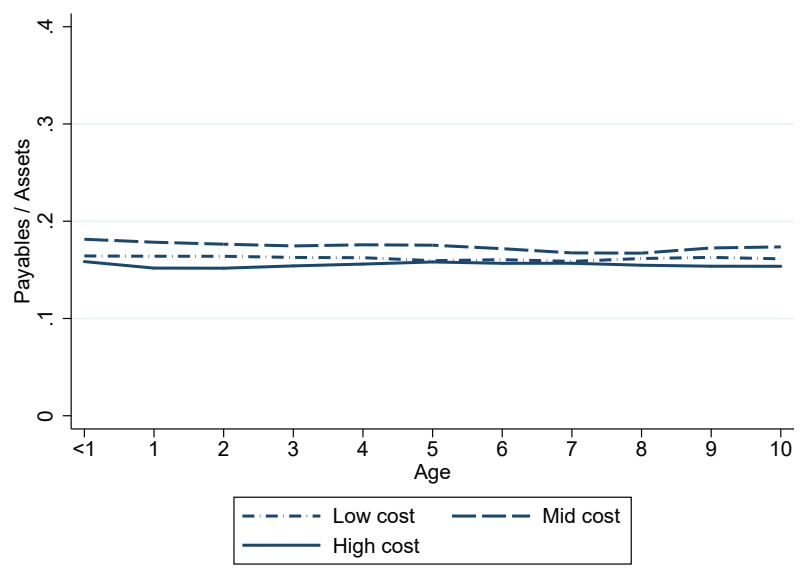

Maturity of total debt (in months)

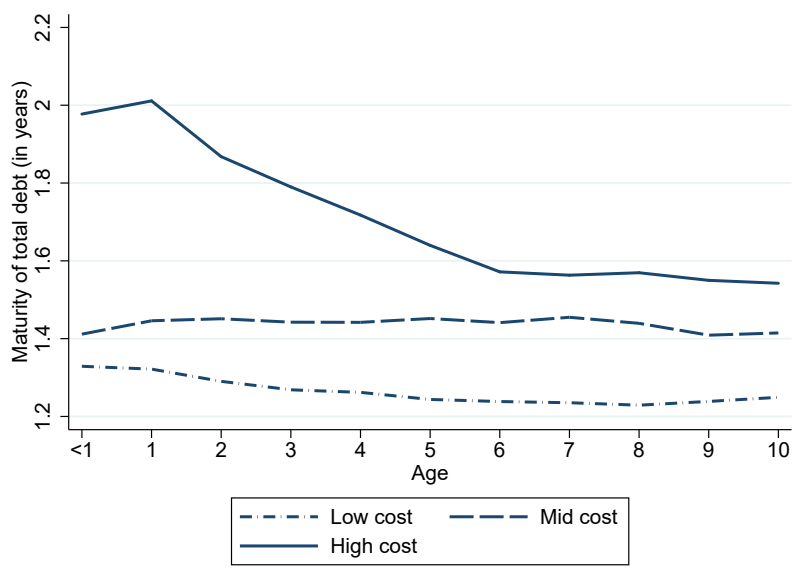

Other financial debt / Assets
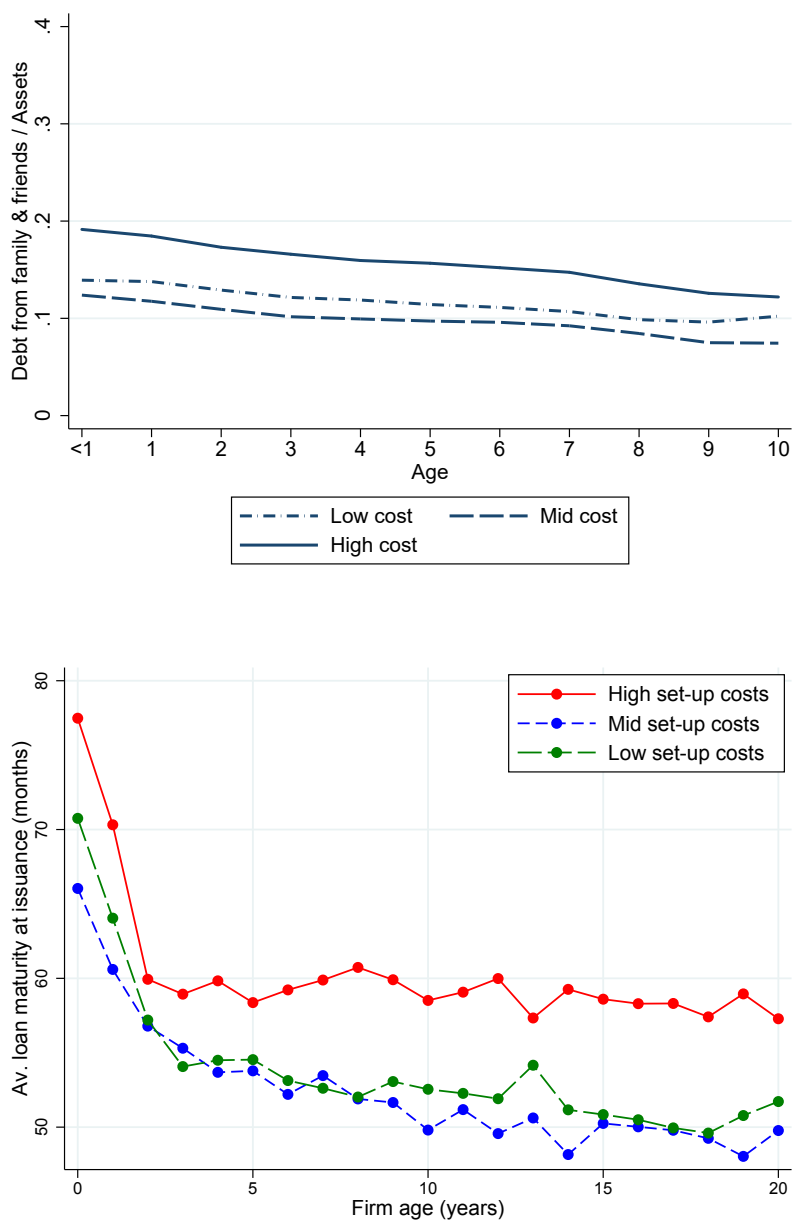
Figure 4: Lending to municipalities across treated and control banks

This figure shows total lending to municipalities across treated and control banks, as defined in Section 4.1. A bank is treated by the Dexia shock if it is highly exposed to municipalities borrowing heavily from Dexia before 2008. The loan volumes are normalized to 100 in 2007Q4.

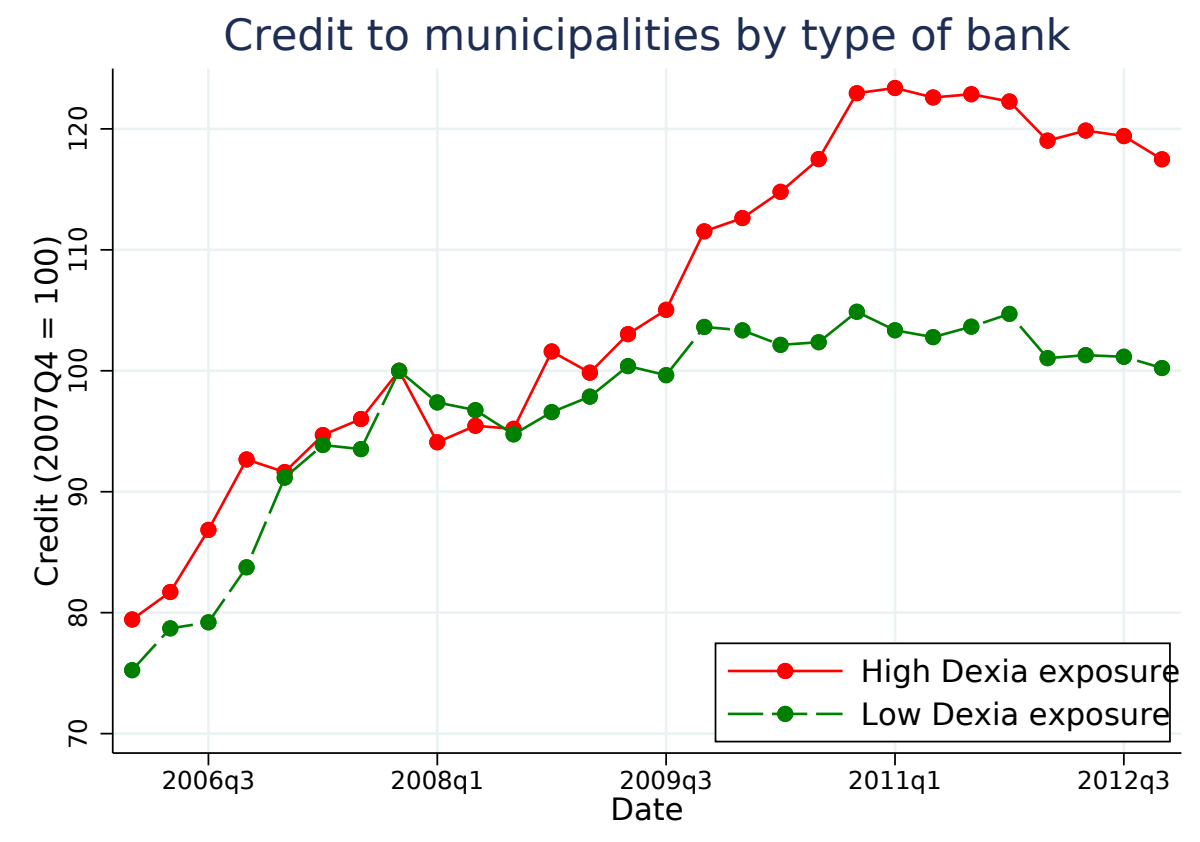


Figure 5: Corporate loan maturity across treated and control banks

This figure shows the initial maturity of loans to young firms (below 24 months) across treated and control banks, as defined in Section 4.1. A bank is treated by the Dexia shock if it is highly exposed to municipalities borrowing heavily from Dexia before 2008 .

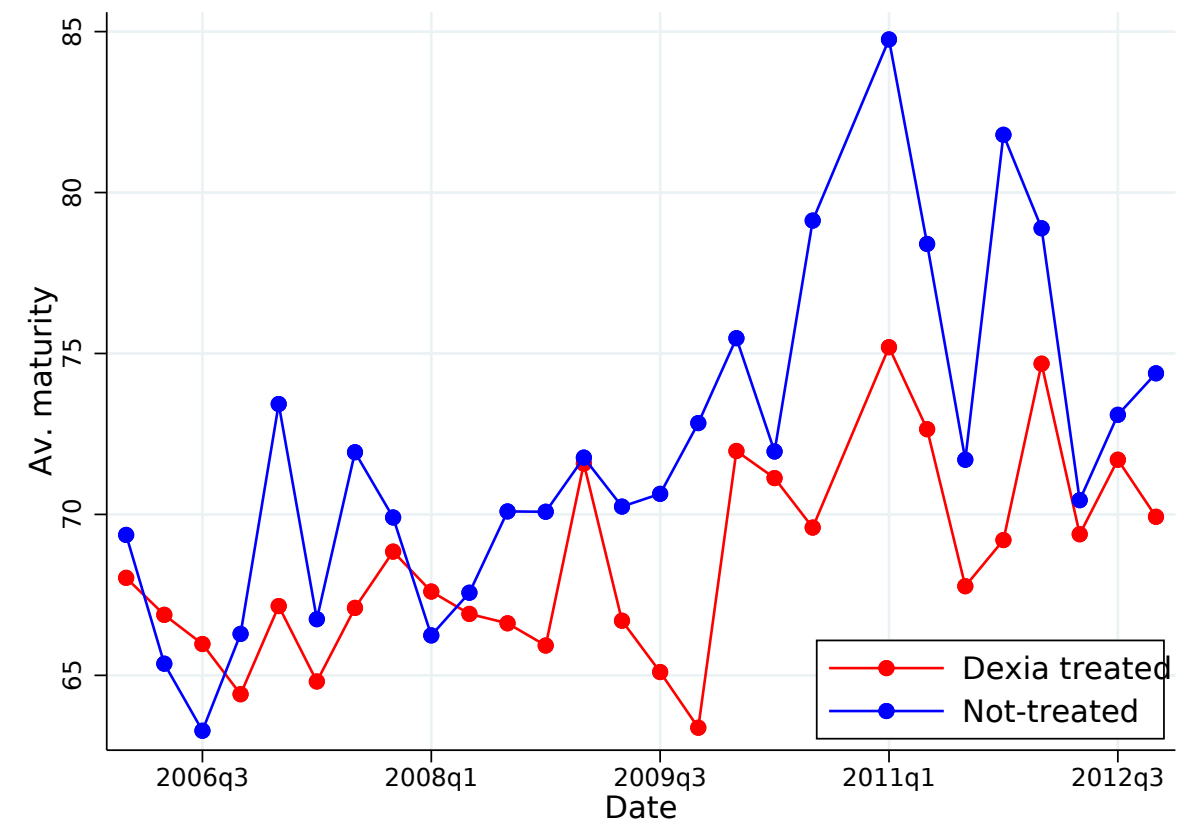


Figure 6: Corporate loan maturity and amount across treated and control banks: By set-up costs

This figure shows the initial maturity of loans and loan amounts to young firms (below 24 months) across treated and control banks, as defined in Section 4.1. A bank is treated by the Dexia shock if it is highly exposed to municipalities borrowing heavily from Dexia before 2008. In each panel, we break down the sample between firms in low and high set-up cost (SUC) industries. 3-digit industries for low and high set-up costs are respectively industries in the bottom and the top tercile of the set-up cost distribution.

Loan maturity, high SUC

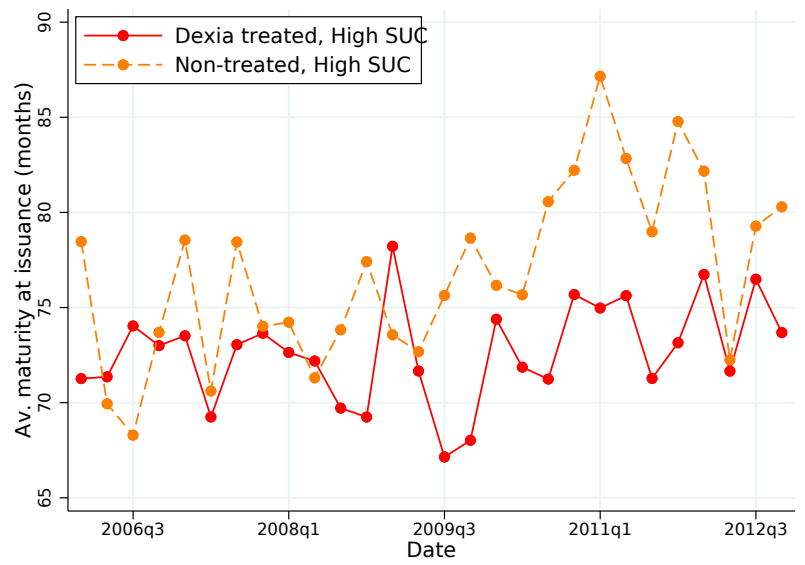

Loan amount, high SUC

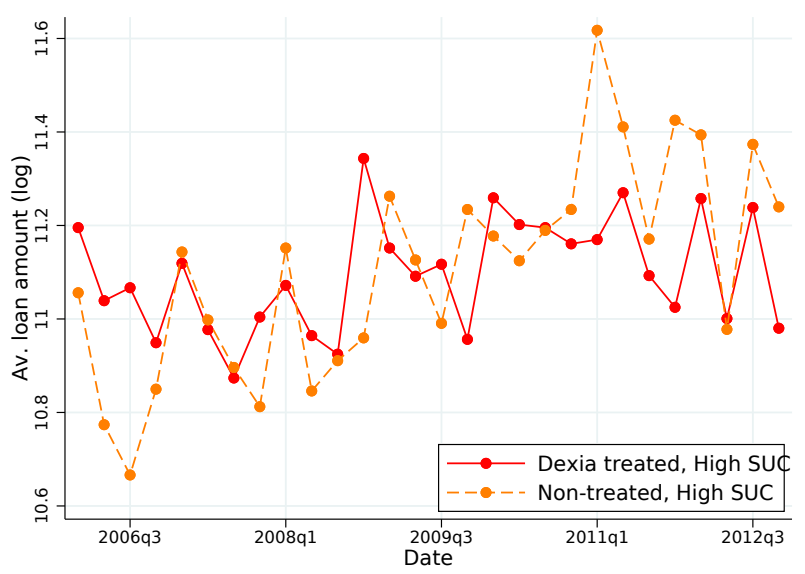

Loan maturity, low SUC

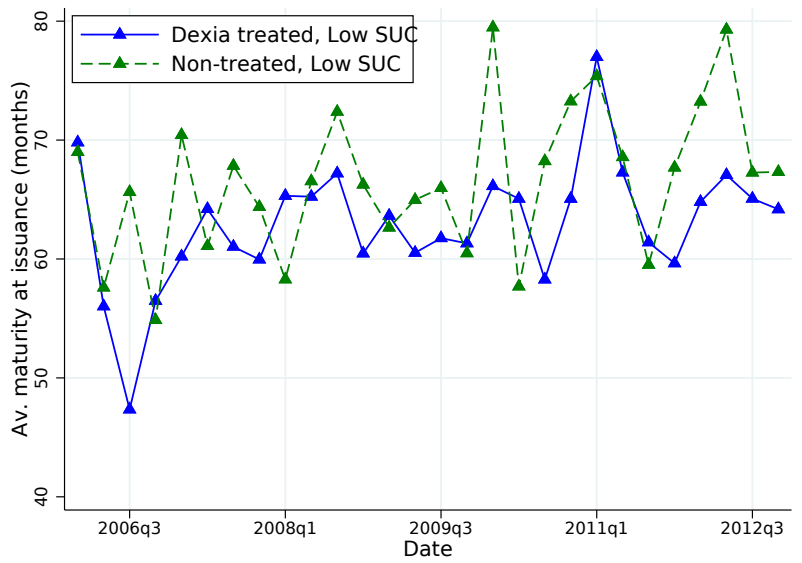

Loan amount, low SUC

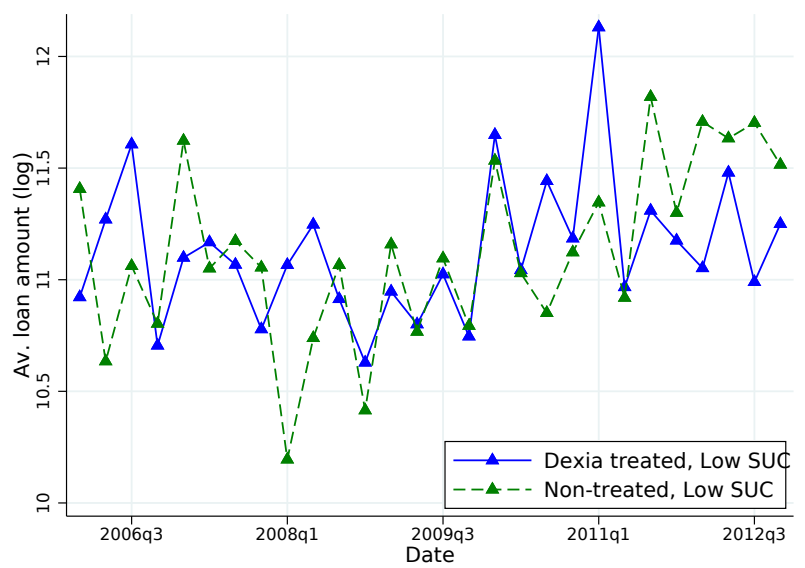




\section{Online appendix}

\section{A Definition of variables}

This appendix provides a detailed description of all variables.

\section{A.1 Firm-level data}

All firm-level data come from firms' tax filings (Liasse fiscale). The variables identifiers are from this filing. Nominal ammounts are expressed in thousands of euros.

- Size: Logarithm of net total assets (variable id: $C O-1 A$ ).

- Age: Difference between reporting year and year of firm creation.

- Total debt / Assets: Sum of all financial and non-financial debt (variable id: $E C)$. Normalized by total assets.

- Financial debt / Assets: Sum of all financial debt (variable id: $E C-D X$ ). Normalized by total assets.

- Bank debt / Assets: Sum of all debt from credit institutions (variable id: $D U)$. Normalized by total assets.

- Other fin. debt / Assets: Sum of other financial debt; comprises mostly debt from equityholders, that is, in our sample, the entrepreneur as well as family and friends (variable id: $D V$ ). Normalized by total assets.

- Accounts payables / Assets: Sum of all debt to suppliers (variable id: $D X$ ). Normalized by total assets.

- Debt maturity (residual): Weighted average maturity of total debt (including accounts payables). The breakdown of the residual maturity of total debt is known for three buckets (up to one year, between one and five years, above five years). We assume that debt with a maturity up to one year has maturity of one year, that debt with a maturity between one and five years has a maturity of three years, and that debt with a maturity above five years has a maturity of seven years. We then compute a weighted average of these maturities, in years (variable id: $V Z$ ). 
- Debt $\leq \mathbf{1 y}$ / Debt: Share of total debt (including accounts payables) that has a residual maturity up to one year (variable id: $V Z$ ). Normalized by total debt.

- Debt $>1 \mathbf{y}$ and $\leq 5 y$ / Debt: Share of total debt (including accounts payables) that has a residual maturity above one year and up to five years (variable id: $V Z)$. Normalized by total debt.

- Debt > 5y / Debt: Share of total debt (including accounts payables) that has a residual maturity above five years (variable id: $V Z$ ). Normalized by total debt.

- PPE / Assets: Sum of net tangible assets (variable id: $(A N-A O)+(A P-$ $A Q)+(A R-A S)+(A T-A U)+(A V-A W)+(A X-A Y))$. Normalized by total assets.

- Intangibles / Assets: Sum of net intangible assets (variable id: $(A B-A C)$ $+(A D-A E)+(A F-A G)+(A H-A I)+(A J-A K)+(A L-A M))$. Normalized by total assets.

- EBITDA / Assets: EBITDA (variable id: $G G$ ). Normalized by total assets.

\section{A.2 Loan-level data}

All loan-level data come from M-Contran, as described in Section 2.1. Borrowing firms are matched with balance sheet data from tax filings. Therefore, all balance sheet variables in loan-level regressions (Size, Financial Debt / Assets, PPE / Assets, EBITDA / Assets) are computed as in Section A.1.

- Loan maturity: Maturity of the loan at issuance, expressed in months.

- Fixed rate loan: Dummy variable equal to 1 if the loan contract has a fixed interest rate.

- Subsidized investment loan: Dummy variable equal to 1 if the interest rate benefits from a public subsidy.

- Regulated loan: Dummay variable equal to 1 if any other regulation impacts the interest rate.

- Standalone SME: Dummy variable equal to 1 if the borrowing firm operates as a standalone company, that is, has no parent company. 


\section{B Additional tests}

Table A1: Test of the balancing hypothesis of covariates for the Diff-in-diff regressions.

Note: The treated group consists of loans granted by banks affected by the Dexia shock. Controls are loans granted by other banks. Only loans to young firms (aged less than 24 months) are included. Period of observation: 2006-2012 (quarterly data). The normalized difference (Imbens and Wooldridge, 2009) is defined as the difference between the means of the treated and of the control group, normalized by the square root of the sum of the variances.

\begin{tabular}{lccc}
\hline \hline & Mean $(1)$ & Mean(0) & $\mathrm{SD}(1-0)$ \\
\hline Subsidized & 0.11 & 0.16 & -0.16 \\
Fixed rate & 0.92 & 0.94 & -0.05 \\
Regulated & 0.09 & 0.11 & -0.05 \\
N Obs & $13,037.00$ & $7,332.00$ & $20,369.00$ \\
\hline \hline
\end{tabular}

Table A2: Test of the balancing hypothesis of covariates for the Diff-in-diff regressions (sub-sample of firms with available balance sheet information).

Note: The treated group consists of loans granted by banks affected by the Dexia shock. Controls are loans granted by other banks. Only loans to young firms (aged less than 24 months) are included. Period of observation: 2006-2012 (quarterly data). The normalized difference (Imbens and Wooldridge, 2009) is defined as the difference between the means of the treated and of the control group, normalized by the square root of the sum of the variances.

\begin{tabular}{lccc}
\hline \hline & Mean(1) & Mean(0) & SD(1-0) \\
\hline Subsidized & 0.11 & 0.16 & -0.17 \\
Fixed rate & 0.90 & 0.91 & -0.03 \\
Regulated & 0.09 & 0.13 & -0.13 \\
Size & 6.05 & 6.08 & -0.03 \\
Leverage & 0.57 & 0.57 & 0.03 \\
PPE/A & 0.26 & 0.27 & -0.04 \\
ROA & 0.07 & 0.07 & 0.03 \\
N Obs & $3,443.00$ & $2,308.00$ & $5,751.00$ \\
\hline \hline
\end{tabular}


Table A3: Residual maturity of total debt of young firms after the Dexia shock

This table estimates a difference-in-differences model with the residual maturity of total debt of young non-financial firms (below 24 months) as dependent variable. The treatment is defined at the bank level, as described in Section 4.1. In sum, a bank is treated by the Dexia shock if it is highly exposed to municipalities borrowing heavily from Dexia before 2008. 3-digit industries for low and high set-up costs (SUC) are respectively industries in the bottom and the top tercile of the set-up cost distribution. Counties with high bank competition are counties with an Herfindhal-Hirschmann index (computed based on banks' local corporate loan shares as of 2007) below the median. The estimation period is from 2006 to 2012. Period fixed effects are dummy variables for the two time periods before and after the Dexia shock of 2008 Q3. Standard errors are clustered at the bank level and are reported in brackets. ${ }^{*},{ }^{* *}$ and ${ }^{* * *}$ denote respectively statistical significance at the $10 \%, 5 \%$ and $1 \%$ levels.

\begin{tabular}{|c|c|c|c|}
\hline & \multicolumn{3}{|c|}{$\begin{array}{l}\text { Dependent variable: } \\
\text { Maturity of total debt }\end{array}$} \\
\hline & All & Low comp. & High comp. \\
\hline Treated $\times$ Post $\times$ HighCost & $\begin{array}{c}-0.664^{* *} \\
{[0.291]}\end{array}$ & $\begin{array}{c}-1.451^{* *} \\
{[0.594]}\end{array}$ & $\begin{array}{l}-0.375 \\
{[0.335]}\end{array}$ \\
\hline Treated $\times$ HighCost & $\begin{array}{l}0.655^{* *} \\
{[0.260]}\end{array}$ & $\begin{array}{c}0.371 \\
{[0.529]}\end{array}$ & $\begin{array}{l}0.650^{*} \\
{[0.300]}\end{array}$ \\
\hline Post $\times$ HighCost & $\begin{array}{c}-0.866^{* * *} \\
{[0.198]}\end{array}$ & $\begin{array}{r}-0.852^{*} \\
{[0.436]}\end{array}$ & $\begin{array}{c}-0.839^{* * *} \\
{[0.221]}\end{array}$ \\
\hline HighCost & $\begin{array}{c}1.359^{* * *} \\
{[0.180]}\end{array}$ & $\begin{array}{c}1.592^{* * *} \\
{[0.395]}\end{array}$ & $\begin{array}{c}1.332^{* * *} \\
{[0.201]}\end{array}$ \\
\hline Size & $\begin{array}{c}1.824^{* * *} \\
{[0.020]}\end{array}$ & $\begin{array}{c}2.050^{* * *} \\
{[0.045]}\end{array}$ & $\begin{array}{c}1.775^{* * *} \\
{[0.022]}\end{array}$ \\
\hline PPE / Assets & $\begin{array}{c}-1.878^{* * *} \\
{[0.075]}\end{array}$ & $\begin{array}{c}-2.496^{* * *} \\
{[0.162]}\end{array}$ & $\begin{array}{c}-1.703^{* * *} \\
{[0.085]}\end{array}$ \\
\hline EBITDA / Assets & $\begin{array}{c}3.463^{* * *} \\
{[0.177]}\end{array}$ & $\begin{array}{c}4.817^{* * *} \\
{[0.392]}\end{array}$ & $\begin{array}{c}3.076^{* * *} \\
{[0.198]}\end{array}$ \\
\hline Within- $R^{2}$ & 0.425 & 0.448 & 0.415 \\
\hline County*Period FE & Yes & Yes & Yes \\
\hline N. Obs & 87,087 & 19,994 & 67,093 \\
\hline
\end{tabular}


Table A4: Size of new loans to young firms after the Dexia shock

This table estimates a difference-in-differences regression with the (log) size of new loans (i.e., loan amounts in euros) to young non-financial firms (aged less than 24 months) as the dependent variable, using the loan-level sample. The treatment is defined at the bank level, as described in Section 4.1. In sum, a bank is treated by the Dexia shock if it is highly exposed to municipalities borrowing heavily from Dexia before 2008. 3-digit industries with low and high set-up costs (SUC) are respectively industries in the bottom and the top tercile of the set-up cost distribution. Loan-level controls are dummy variables for subsidized, fixed rate and regulated loans respectively. Counties with high bank competition are counties with an Herfindhal-Hirschmann index (computed based on banks' local corporate loan shares as of 2007) below the median. The estimation period is from 2006 to 2012. Period fixed effects are dummy variables for the two time periods before and after the Dexia shock of 2008 Q3. Standard errors are clustered at the bank level and are reported in brackets. ${ }^{*},{ }^{* *}$ and *** denote respectively statistical significance at the $10 \%, 5 \%$ and $1 \%$ levels.

\begin{tabular}{|c|c|c|c|c|c|c|}
\hline & \multicolumn{2}{|c|}{ All $<2 y$} & \multirow[t]{2}{*}{ Low SUC } & \multicolumn{3}{|c|}{ High SUC } \\
\hline & & & & & Low comp. & High comp. \\
\hline \multirow[t]{2}{*}{ Treated bank $\times$ Post } & -0.059 & -0.000 & -0.013 & -0.081 & -0.113 & -0.086 \\
\hline & {$[0.063]$} & {$[0.066]$} & {$[0.131]$} & {$[0.077]$} & {$[0.107]$} & {$[0.077]$} \\
\hline \multirow[t]{2}{*}{ Treated bank } & -0.052 & -0.073 & -0.091 & -0.030 & 0.005 & -0.026 \\
\hline & {$[0.068]$} & {$[0.069]$} & {$[0.111]$} & {$[0.077]$} & {$[0.081]$} & {$[0.085]$} \\
\hline \multirow[t]{2}{*}{ Constant } & $11.759^{* * *}$ & $11.712^{* * *}$ & $12.261^{* * *}$ & $11.811^{* * *}$ & $11.322^{* * *}$ & $11.922^{* * *}$ \\
\hline & {$[0.179]$} & {$[0.163]$} & {$[0.173]$} & {$[0.232]$} & {$[0.167]$} & {$[0.222]$} \\
\hline Industry FE & Yes & No & Yes & Yes & Yes & Yes \\
\hline Quarter FE & Yes & Yes & Yes & Yes & Yes & Yes \\
\hline County FE & Yes & No & Yes & Yes & Yes & Yes \\
\hline Industry $\times$ Period FE & No & Yes & No & No & No & No \\
\hline County $\times$ Period FE & No & Yes & No & No & No & No \\
\hline Loan controls & Yes & Yes & Yes & Yes & Yes & Yes \\
\hline Nb clust & 164 & 163 & 139 & 148 & 108 & 143 \\
\hline Observations & 20,368 & 20,282 & 3,006 & 12,427 & 3,243 & 9,122 \\
\hline Adj. R2 & 0.19 & 0.20 & 0.29 & 0.10 & 0.11 & 0.10 \\
\hline
\end{tabular}


Table A5: Growth of young firms after the Dexia shock

This table estimates a difference-in-differences model with several measures of future firm size (log total assets and log fixed assets, observed two years after a loan is granted) as dependent variables. The sample of borrowing firms includes young non-financial firms (below 36 months). In Panel A, the "Dexia" treatment is defined at the bank level, as described in Section 4.1. 3-digit industries with high set-up costs (SUC) are industries in the top tercile of the set-up cost distribution. The estimation period is from 2006 to 2012. In column 2 and five (resp., 3 and 6), the sample is limited to firms located in counties with low (resp. high) levels of local bank competition. In Panel B, the treatment is defined at the county level. In sum, a county is treated by the Dexia shock if it is highly exposed to banks that lend heavily do Dexia-exposed municipalities before 2008. The definition of firm-level variables is provided in Appendix A. Standard errors, clustered at the bank level (Panel A), are reported in brackets. ${ }^{*},{ }^{* *}$ and ${ }^{* * *}$ denote respectively statistical significance at the $10 \%, 5 \%$ and $1 \%$ levels.

\begin{tabular}{|c|c|c|c|c|c|c|}
\hline \multicolumn{7}{|c|}{ Panel A: Loan-level dataset } \\
\hline & \multicolumn{3}{|c|}{$\operatorname{Assets}(+2)$} & \multicolumn{3}{|c|}{ Fixed ass. $(+2)$} \\
\hline & (1) & $(2)$ & $(3)$ & (4) & $(5)$ & $(6)$ \\
\hline & All & Low Comp & High Comp & All & Low Comp & High Comp \\
\hline \multirow[t]{2}{*}{ Treated bank $\times$ Post $\times$ HighCost } & -0.199 & -0.178 & -0.199 & -0.126 & 0.128 & -0.290 \\
\hline & {$[0.130]$} & {$[0.202]$} & {$[0.157]$} & {$[0.184]$} & {$[0.285]$} & {$[0.243]$} \\
\hline \multirow[t]{2}{*}{ Treated bank $\times$ HighCost } & $0.210^{*}$ & 0.110 & $0.263^{*}$ & 0.108 & 0.006 & 0.173 \\
\hline & {$[0.121]$} & {$[0.145]$} & {$[0.142]$} & {$[0.132]$} & {$[0.214]$} & {$[0.178]$} \\
\hline \multirow[t]{2}{*}{ Post $\times$ HighCost } & 0.106 & 0.130 & 0.094 & $0.282^{*}$ & 0.075 & $0.418^{*}$ \\
\hline & {$[0.121]$} & {$[0.174]$} & {$[0.150]$} & {$[0.153]$} & {$[0.223]$} & {$[0.217]$} \\
\hline \multirow[t]{2}{*}{ Treated bank $\times$ Post } & 0.056 & -0.017 & 0.108 & 0.104 & 0.038 & 0.218 \\
\hline & {$[0.117]$} & {$[0.162]$} & {$[0.152]$} & {$[0.154]$} & {$[0.193]$} & {$[0.214]$} \\
\hline \multirow[t]{2}{*}{ HighCost } & $-0.251^{* *}$ & -0.080 & $-0.338^{* *}$ & $0.577^{* * *}$ & $0.697^{* * *}$ & $0.521^{* * *}$ \\
\hline & {$[0.111]$} & {$[0.116]$} & {$[0.134]$} & {$[0.113]$} & {$[0.156]$} & {$[0.166]$} \\
\hline \multirow[t]{2}{*}{ Age } & $0.268^{* * *}$ & $0.250^{* * *}$ & $0.263^{* * *}$ & $0.249^{* * *}$ & $0.261^{* * *}$ & $0.236^{* * *}$ \\
\hline & {$[0.024]$} & {$[0.044]$} & {$[0.031]$} & {$[0.043]$} & {$[0.066]$} & {$[0.056]$} \\
\hline Bank FE & Yes & Yes & Yes & Yes & Yes & Yes \\
\hline County $\times$ Period FE & Yes & Yes & Yes & Yes & Yes & Yes \\
\hline $\mathrm{Nb}$ clusters & 142 & 98 & 137 & 136 & 87 & 128 \\
\hline Observations & 9,921 & 2,851 & 7,057 & 5,988 & 1,704 & 4,264 \\
\hline Adj. $R^{2}$ & 0.14 & 0.11 & 0.16 & 0.16 & 0.18 & 0.15 \\
\hline
\end{tabular}

Panel B: Firm-level dataset

Dependent variable:

Size after 2 years

\begin{tabular}{ccc}
\multicolumn{3}{c}{ Size after 2 years } \\
\hline All & Low comp. & High comp. \\
\hline & & \\
-0.032 & -0.114 & 0.005 \\
{$[0.048]$} & {$[0.092]$} & {$[0.056]$} \\
-0.055 & -0.065 & -0.057 \\
{$[0.041]$} & {$[0.079]$} & {$[0.049]$} \\
0.016 & -0.032 & 0.027 \\
{$[0.033]$} & {$[0.067]$} & {$[0.038]$} \\
$0.235^{* * *}$ & $0.295^{* * *}$ & $0.218^{* * *}$ \\
{$[0.029]$} & {$[0.059]$} & {$[0.033]$} \\
0.068 & 0.066 & 0.070 \\
Yes & Yes & Yes \\
82,072 & 18,545 & 63,527
\end{tabular}




\section{Additional figures}

Figure A1: Correlation between set-up costs and other industry characteristics

This figure plots the correlation between our measure of industry-level set-up costs and other industry characteristics based, using the sample of firms from Diane. Each industry-level ratio is computed as the median in the industry of within-firm averages of the ratio over 2006-2016. The Rajan-Zingales (RZ) index of financial dependence is measured at the firm level as (CAPEX - EBITDA)/CAPEX.

Panel A: CAPEX/Assets

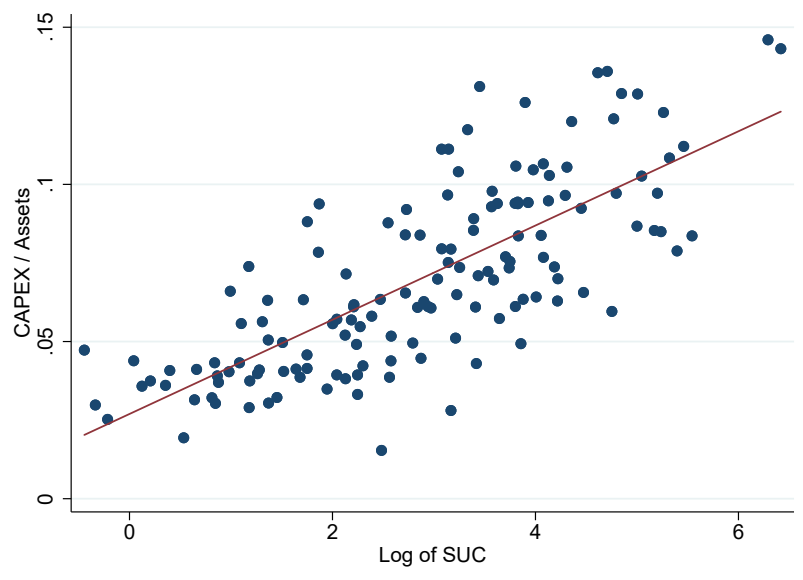

Panel C: Size

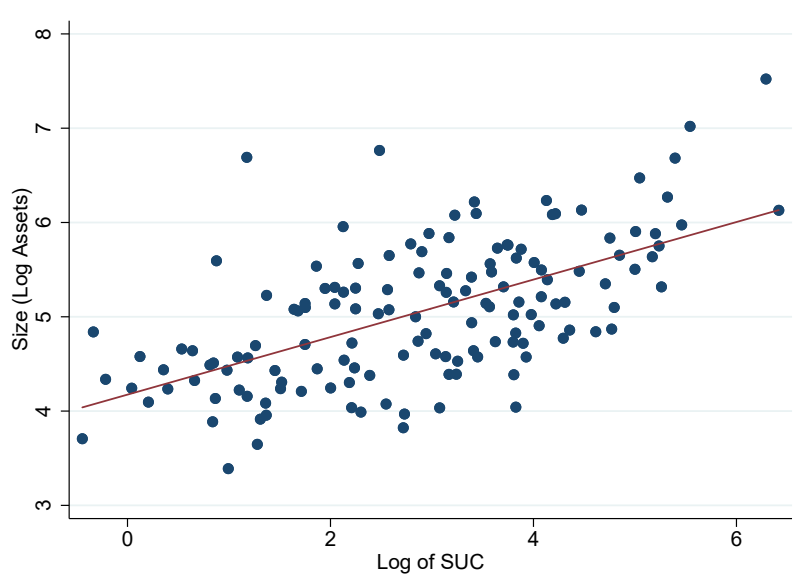

Panel B: PPE/Assets

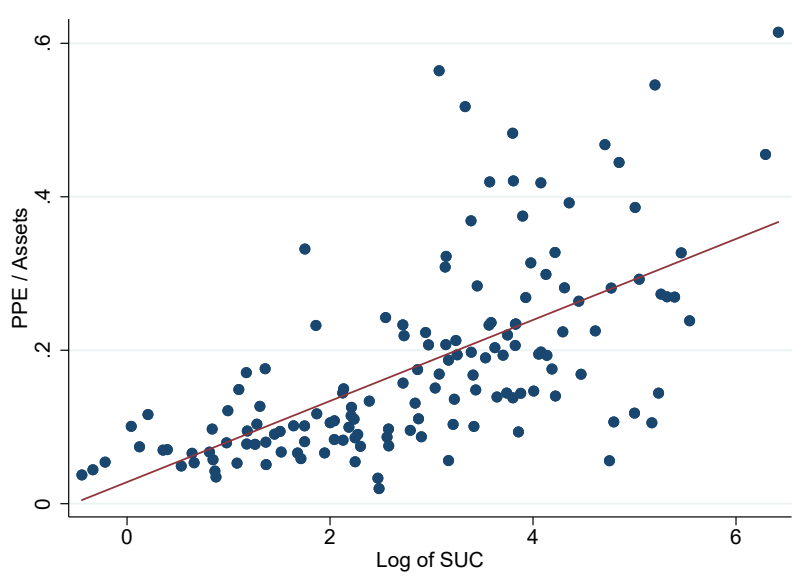

Panel D: Rajan-Zingales financial dependence

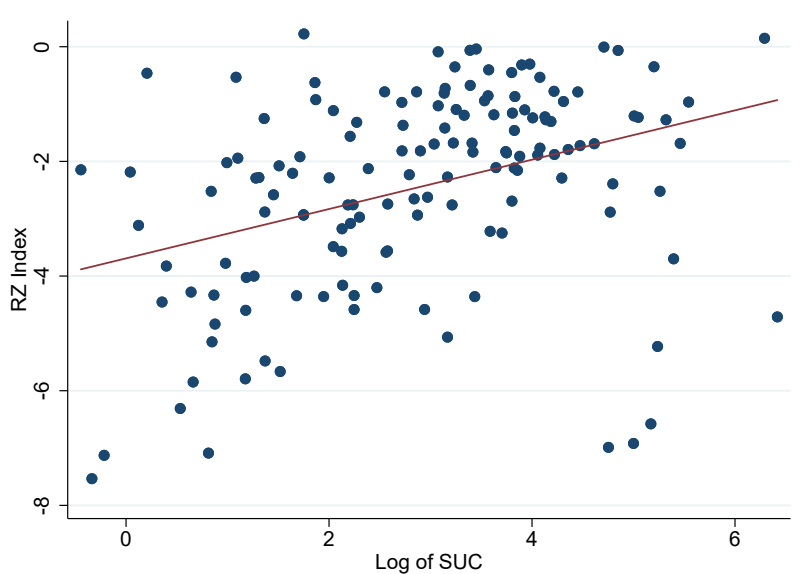


Figure A2: Intensity of treatment and competition at the county level

This figure plots the intensity of the treatment and of bank competition at the county level (département). Panel A shows county-level market shares in 2007 of banks treated by the "Dexia shock." A bank is treated nation-wide whenever its share of loans to municipalities borrowing from Dexia was above the sample median in June 2007. Darker areas denote upper quartiles of the distribution of market shares across counties in 2007. Panel B shows Herfindahl-Hirschmann indices (HHI) for loans to non-financial corporations (NFCs) at the county level in 2007. Darker areas denote upper quartiles of the distribution of HHI and correspond to lower local levels of bank competition.

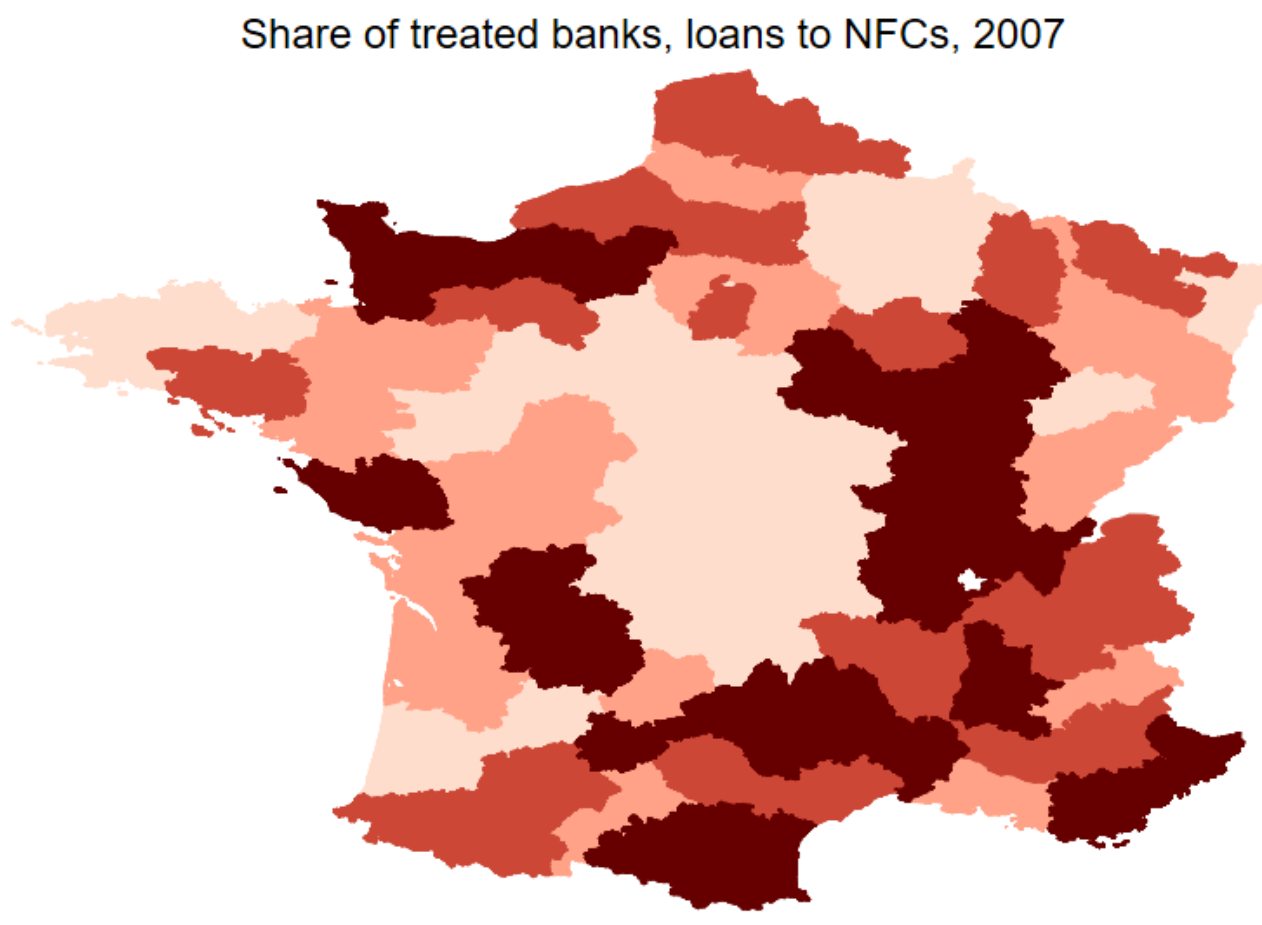

$.7943432-.9929422$ $6727047-.7943432$ $3838101-.6727047$ $0694144-.3838101$

\section{Bank competition (HHI, loans to NFCs, 2007)}

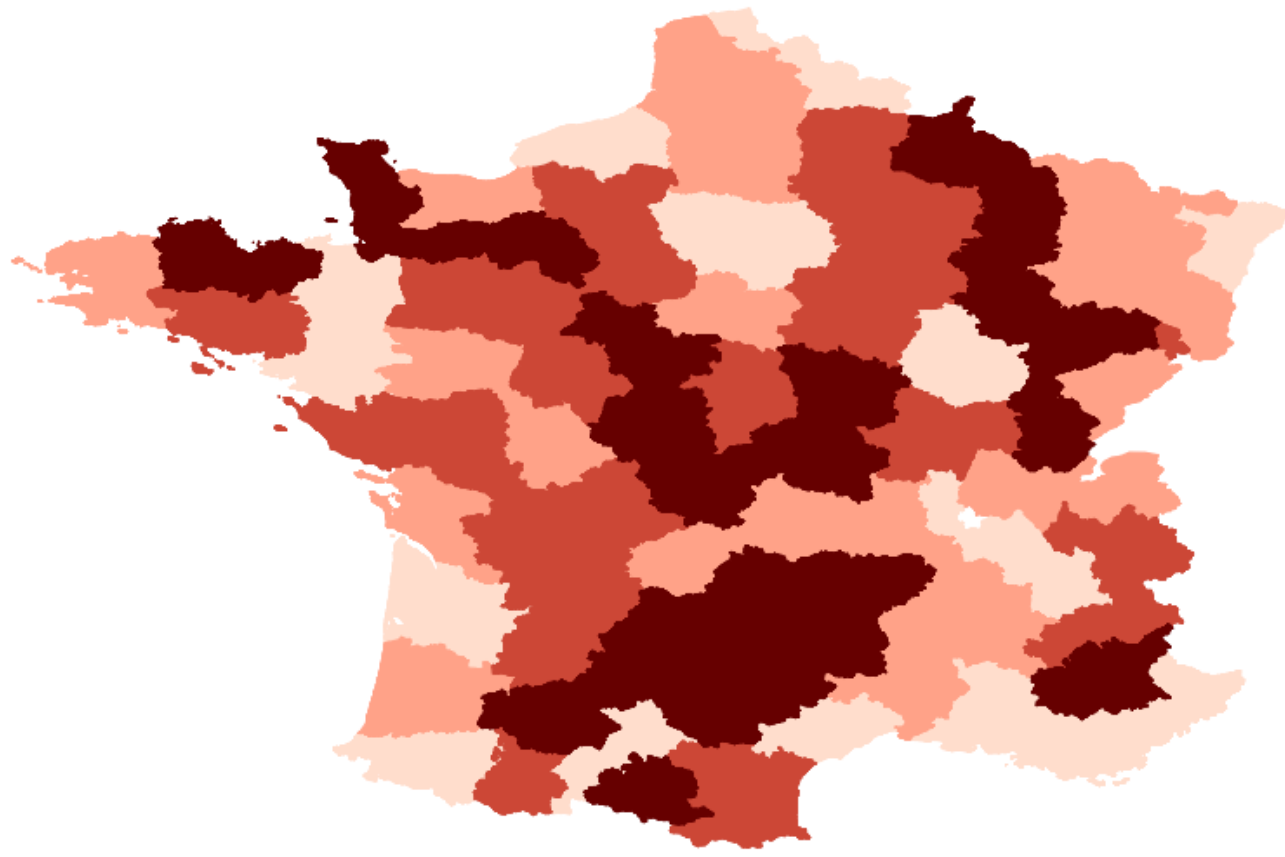

$.0246778-.0580348$ 